\title{
LA SEU D'URGELL, EL ÚLTIMO CONJUNTO DE IGLESIAS. LITURGIA, PAISAJE URBANO Y ARQUITECTURA ${ }^{1}$
}

\author{
LA SEU D'URGELL, THE LAST GROUP OF CHURCHES. \\ LITURGY, CITYSCAPE AND ARCHITECTURE
}

\author{
EDUARDO CARRERO SANTAMARÍA \\ Universitat de les Illes Balears
}

\begin{abstract}
Resumen: En la Edad Media central, la catedral de la Seu d'Urgell estaba integrada por una familia de iglesias canónica, que se mantuvieron en uso hasta fechas tardías, cuando la tendencia generalizada era la asimilación en un espacio único de edificios dispersos altomedievales. $\mathrm{Su}$ origen debe buscarse a comienzos del siglo $\mathrm{XI}$, cuando en cerca de tres décadas se redefinió por completo todo el conjunto catedralicio, con un total de cuatro iglesias - tres de ellas documentadas por primera vez en estas fechas- rodeando a la principal de Santa María. En este trabajo también se estudian las relaciones litúrgicas entre las cinco iglesias, su vinculación a la canónica de la catedral y su advocación a algunos de los más importantes centro de peregrinación de la época.
\end{abstract}

Palabras clave: Seu d'Urgell; Catedral; Conjunto de iglesias; Arquitectura; Liturgia; Peregrinación.

\begin{abstract}
In the central Middle Ages, the cathedral of the Seu d'Urgell was integrated by a canonical family of churches, which were kept in use up to late dates, when the widespread trend was the assimilation in an unique sacred space the ensembles of dispersed churches of the Early Middle Ages. Its origin must be searched at the beginning of the 11th century, when in near three decades the whole cathedral set was completely re-defined, with a whole of four churches - three of them documented by the first time during these dates- surrounding the principal church of Santa Maria. This article deals also with the liturgical relations between the five churches, its connections to the common life of the cathedral chapter and its dedication to the most important pilgrimage sites of the times.
\end{abstract}

Keywords: Seu d'Urgell; Cathedral; Family of Churches; Architecture; Liturgy; Pilgrimage.

\section{SUMARIO}

1. Urgell I: La penumbra del siglo IX.- 2. Urgell II: El obispo Ermengol o la redefinición del conjunto arquitectónico. 2.1. Sancte Marie Sedis Urgellensis. 2.2. Sanctus Petrus de Sede. 2.3. Sanctus Michael de Sedis. 2.4. Sancta Eulalia. 2.5. Sanctum Sepulcrum de Sede.- 2.6. La canónica.- 3. La catedral y sus iglesias. La ciudad del siglo XI. 3.1. Los cabildos de la Seu. 4. Testimonios litúrgicos del siglo XII. 4.1. Topografía urbana, santos lugares y liturgia estacional.

${ }^{1}$ El presente trabajo se inscribe en el proyecto de investigación Arquitectura y liturgia. El contexto artístico de las consuetas catedralicias de la Corona de Aragón, HAR2009-09366. 
Siguiendo las constantes de la arquitectura altomedieval europea, un establecimiento religioso no estaba definido por una iglesia única, sino por un conjunto de núcleos cultuales que respondían a necesidades litúrgicas concretas. Desde una perspectiva general, los conjuntos de iglesias estuvieron motivados por la disgregación espacial de las funciones religiosas que posteriormente - en un proceso que se inicia con la cultura del Románicose englobarían en un gran templo pero también, en muchos casos, estuvieron mediatizados por usos procesionales a imitación de los grandes centros de la época, como Roma o Jerusalén. A pesar de formar parte de un fenómeno común, en la mayoría de las ocasiones dichos conjuntos de iglesias y su pluralidad de ámbitos de reunión se fundamentaban en usos particulares a los que se adaptaban los modos litúrgicos difundidos desde otros lugares. Así, el citado marco procesional de Roma o Jerusalén era amoldado a las singularidades devocionales, arquitectónicas e incluso urbanísticas de cada territorio en cuestión ${ }^{2}$.

Un caso particular sobre el que no se ha insistido lo suficiente es el de la Seu d'Urgell, familia de iglesias canónica que se interna en fechas tardías, cuando la tendencia generalizada era la asimilación en un espacio único de los usos litúrgicos que habían caracterizado el esparcimiento topográfico de la arquitectura religiosa en conjuntos múltiples. Si los investigadores que se han acercado hasta nuestra catedral han insistido sobre los problemas de filiación y cronología de la fábrica conservada, en pocas ocasiones se ha valorado la importancia del conjunto catedralicio hasta finales del siglo XII, la época que debiéramos reconsiderar como la edad de oro de la Seu ${ }^{3}$. Avanzando algunos de los puntos básicos de este trabajo, en la capital del Alt Urgell nos hallamos ante una compleja historia constructiva en la que, desde el siglo IX y la conformación de lo que denominaremos Urgell I, se pasó a comienzos del XI a la organización de Urgell II en una familia de cinco iglesias que, a su vez y a partir de la segunda mitad del siglo XII, sufriría un trascendental proceso de mutación funcional - esto es, Urgell III-, con la construcción de la catedral actual y la progresiva pérdida de costumbres y redefinición de usos de los edificios que concretaron el viejo conjunto del siglo XI.

Nuestro análisis, de carácter fundamentalmente heurístico, toma como base la trascendental labor de edición documental encabezada por Cebrià Baraut y su sistemática publicación de los fondos del Arxiu Capitular urgelitano producidos entre los siglos IX y XII, la edición por Miquel dels Sants Gros de la consueta más antigua, y la publicación fragmentaria de la consueta del siglo XV (Arxiu Capitular de la Seu d'Urgell, ms. 2048) junto

\footnotetext{
${ }^{2}$ Eduardo CARRERO SANTAMARÍA, La arquitectura medieval al servicio de las necesidades litúrgicas. Los conjuntos de iglesias, "Anales de Historia del Arte", volumen extraordinario (2009), pp. 61-97.

${ }^{3}$ Los lugares comunes que la historiografía había ido acumulando sobre la iglesia de Santa María y sobre su documentado maestro Raimon Lambard han sido revisados por Joan DURANPORTA, Sobre l'origen de Raimon Lambard, obrer de la catedral d'Urgell, "Locvs Amoenus", 8 (2005-2006), pp. 19-28, e ID., Lombardos en Cataluña? Construcción y pervivencia de una hipótesis, "Anales de Historia del Arte", Volumen Extraordinario (2009), pp. 247-262.
} 
al procesionario catedralicio de 1527 -el último libro litúrgico propio de la catedral- realizada por Francesc Xavier Altés i Aguiló ${ }^{4}$. La documentación de los siglos XIII al XVI - especialmente actas y estatutos capitularescontribuirá sin duda a rellenar las lagunas que, para algunos asuntos clave, aún se desprenden de este trabajo.

\section{URGELL I: LA PENUMBRA DEL SIGLO IX}

Yendo a los orígenes, la historia de la ciudad previa al siglo IX es motivo de discusión científica. Hasta fechas recientes, se pensó que la vieja ciudad romana y visigoda estuvo inicialmente situada en el monte de Castellciutat. Tras la entrada en la zona de las tropas de 'Abd al-Malik en 793 y la época herética del obispo Félix d’Urgell (786-799), la ciudad episcopal sería trasladada al actual llano al borde del Segre, llegando a coexistir dos núcleos urbanos de los que la catedral sería un vicus creado en el siglo IX, para terminar convirtiéndose en la ciudad principal en los siglos centrales de la Edad Media ${ }^{5}$. La arqueología ha destacado, por el contrario, que existen indicios de una necrópolis tardoantigua en el actual núcleo urgelitano -con enterramientos distribuidos entre el claustro catedralicio y la fachada norte del templo principal-, restos junto al carrer Major -interpretados como vestigios de una puerta trigémina enfrentada con la fachada occidental de la catedral-, $\mathrm{y}$ varios fragmentos edilicios en el entorno de la iglesia de Santa Eulalia ${ }^{6}$.

\footnotetext{
${ }^{4}$ Cebrià BARAUT I OBIOLS, Els documents dels segles IX $i$ X, conservats a l'Arxiu Capitular de la Seu d'Urgell, "Urgellia" 2 (1979), pp. 7-145; ID., Els documents, dels anys 981-1010, de l'Arxiu Capitular de la Seu d'Urgell, "Úrgellia”, 3(1980), pp. 7-166; ID., Els documents, dels anys 1010-1035, de l'Arxiu Capitular de la Seu d'Urgell, "Urgellia", 4 (1981), pp. 7-186; ID. Els documents, dels anys 1036-1050, de l'Arxiu Capitular de la Séu d'Urgell, "Urgellia" '5 (1982), pp. 7-158; ID., Els documents, dels anys 1051-1075, de l'Arxiu Capitular de la Śeu d'Urgell, “Urgellia”, 6' (1983), pp. 7-243; ID. Els documents, dels anys 1076-1092, de l'Arxiu Capitular de la Seu d'Urgell, "Urgellia”, 7(1984-1985), pp. 7-218; ID. Els documents, dels anys 1093-1100, de l'Arxiu Capitular de la Seu d'Urgell. "Ưrgellia", 8 (1986-1987) pp. 7-149; ID. Els documents, dels anys 1101-1150, de l'Arxiu Capitular de' la Seu d'Urgell, "Urgellia" 9 (1988-189), pp. 7-570; ID., Els documents, dels anys 1151-1190, de l'Arxiu Capitular de la Seu d'Urgell, "Urgellia", 10 (1990-1991), pp. 7-349; Index dels documents de l'Arxiu Capitular de la Seu d'Urgell, publicats en els volums IX-X d'Urgellia Ibid., pp. 473-625; ID. , Els documents, dels anys 1991-1200, de l'Arxiu Capitular de la Seu d'Urgell, "Úrgellia”, 11 (1992-1993), pp. 7-160; Miquel dels Sants GROS I PUJOL, La Consueta antiga de la Seu d'Urgell (Vic, Mus. Episc., Ms. 131), "Urgellia", 1 (1978) pp. 183-266. ID. Un fragment de l'antiga consueta de la Seu d'Urgell' "Urgellia”,'15 (2002-2005), pp. 191-199, y El processoner de la Seu d'Urgell imprès l'any 1527, ed. Francesc Xavier Altés 1 Aguiló, Barcelona, 2007.

${ }^{5}$ Jaime VILlanUEVA, Viage literario a las Iglesias de España, 22 vols., Madrid, 1803-1852, IX, pp. 165-166; Carme BATLLE I GALLART, Els orígens medievals de la Seu d'Urgell, Barcelona, 1979, pp. 7-11; ID., La Seu d'Urgell medieval: La ciutat $i$ els seus habitants, Barcelona, 1985, pp. 17-22; Cebrià BARAUT I OBIOLS, El lloc de Ciutat, primitiu nucli urbà de la Seu d'Urgell, de l'època romana a la fi de l'Edat Mitjana, "Urgellia" 8(1986-1987), pp. 483492, reed. en Església i Bisbat d'Urgell. Recull de treballs, La Seu d'Urgell, 2003, pp. 47-58. Una aproximación a los orígenes de la población urgelitana en José Arturo PÉREZ ALMOGUERA, De la arketurki ' prerromana a la 'Vrgellum'visigoda, ¿una continuidad?, "Cypsela”, 13 (1996), pp. 153-160.

${ }^{6}$ Maria Àngels RuF y Albert VILLARÓ, L’església románica de Santa Eulàlia de la Seu d'Urgell, "Urgellia", 11 (1992-1993), pp. 487-509; Albert VILLARÓ I BOIX, La ciutat de la Seu $i$ la muralla, en "Catalunya Romànica", VI, L'Alt Urgell, Andorra, Barcelona, 1992, pp. 311 313; ID., Hêrcules i la ciutat: Un passeig per la història de la Seu. Barcelona, 1995, pp. 18-45; ID., Intervencions arqueológiques a la Seu d'Urgell: cap a un horitzó romà tardà, "Revista
} 
Hasta la construcción de las murallas y ampliación del perímetro urbano a finales del siglo XII y su remodelación en el XIV, parece que la Seu d'Urgell estaba cerrada sobre sí misma, con el caserío actuando como protección en la que las ventanas al exterior no se abrían hasta una altura considerable y con un torrente, un brazo del río Segre, actuando como barrera natural al menos en uno de sus laterales ${ }^{7}$. Es en el momento previo al encastillamiento de la catedral y a la coetánea fortificación de la ciudad cuando, desde una perspectiva documental, comenzamos a tener noticias sobre un conjunto religioso que siempre contó con una iglesia principal dedicada a la Virgen, como certifican los documentos más antiguos conservados. El acta de consagración en 839 - sospechosa de falsedad o no- la reconoce como principalem ecclesiam sancte Marie $^{8}$. A ésta pronto se añadieron otros edificios religiosos. En el año 993 se documenta una dedicación al Bautista, localizada junto a la catedral y cuyo altar fue el escenario legal de la publicación del testamento de Borrell II: ...per reliquias sancti Iohannis Babtiste cuius baselica sita est in comitatum Urgilitensis infra domum sancte Marie Sedis Vicho, supra cuius sacro et sancto altario ubi has condiciones manibus nostris continemus... ${ }^{9}$. Lo conflictivo en la ubicación de este espacio es el infra domum con que se refiere a la catedral de Santa María, como espacio anejo y que parece colocarlo en el interior de ésta, a pesar de otorgarle el título de baselica. Si Puig i Cadafalch consideró esta nota diplomática la posible alusión a una cabecera triabsidada en el templo principal ${ }^{10}$, en mi opinión podría estar refiriéndose al baptisterio catedralicio, siguiendo la tradicional dedicación de los espacios bautismales a San Juan y entendido como ámbito anejo al templo mayor. De aquí se extraería la aparentemente contradictoria duplicidad de alusiones al mismo, siguiendo un planteamiento muy cercano al propuesto para la catedral de Vic anterior a su reconstrucción

d'Arqueologia de Ponent", 8 (1998), pp. 193-196; ID., Excavacions d'urgència a la ciutat d'Urgell: una aproximació als seus orígenes tardoromans, en "Comerc i vies de comunicació (1000 a.C.- 700 d.C.). XI col-loqui internacional d'arqueologia de Puigcerdà. Puigcerdà, 31 d'octubre i 1 de novembre de 1997", Puigcerdà, 1998, pp. 435-447, e ID., Ciutat d'Urgell, en "Del Romà al Romànic. Història, art i cultura de la Tarraconense mediterrània entre els segles IV i X". Barcelona, 1999, pp. 94-95; Joan Albert ADELL I GISBERT, Pere BESERAN I RAMON, Albert SIERRA I REGUERA y Albert VILLARÓ I BOIX, La catedral de la Seu d'Urgell, Barcelona, 2000 , pp. 23-24. Como visión de conjunto, recogiendo estas noticias, Josep Maria GURT ESPARRAGUERA, Les ciutats i l'urbanisme, en "Del Romà al Romànic", op . cit., pp. 63-76.

${ }^{7}$ Pere Pujol I TuBAu, La muralla medieval de la Seu d'Urgell. "El Cadí", V (1934), reed. en Pere PUJOL I TUBAU, Obra completa, ed. Joan RIERA I SIMÓ, Vall d'Andorra, 1984, pp. 555568. BATLlE, Els orígens medievals de la Seu..., op. cit. pp. 14 y 19-20; ID., La Seu d'Urgell medieval..., op. cit., pp. 23, y VILLARó, La ciutat de la Seu i la muralla, op. cit., pp. 312-313. Se trata de una solucion defensiva común a otros lugares y en determinados barrios dentro de encintados urbanos mayores.

${ }^{8} \mathrm{Cf}$. Pere PUjOL I TUBAU, L'acta de consagració i dotació de la catedral d'Urgell, de l'any 819 o 839, "Estudis Romànics", II (1917), pp. 92-115, reed. en Obras completas, op. cit., pp. 87-106; Cebrià BARAUT, La data de l'acta de consagració de la Catedral carolíngia de la Seu d'Urgell, "Urgellia", VII (1984-1985), pp. 515-525, reed. en Església i Bisbat d'Urgell..., op. cit., pp. 103-121, y ahora, ID., Les actes de consagracions d'esglesies de l'antic bisbat d'Ürgeli (segles IX-XII), La Seu d'Urgell, 1986, doc. 2, pp. 53-56.

${ }^{9}$ Publ. BARAUT, Els documents, dels anys 981-1010, op. cit., doc. 233, p. 66.

${ }^{10}$ Josep Puig I CADAfalch y Pere Pujol i Tubau, Santa Maria de la Seu d'Urgell, Barcelona, 1918 , p. 11 . 
del siglo $\mathrm{XI}^{11}$. Poco más podemos añadir sobre Santa María y su basílica de San Juan.

El siguiente espacio cultual del conjunto catedralicio urgelitano se documenta en el año 840. El conde Seniofred hacía donación de un terreno urbano a Santa María de la Seu lindero con las iglesias de San Pedro y San Andrés. Esta doble advocación ha sido identificada con el templo de San Pedro, localizado a una treintena de metros de la fachada meridional de la catedral $^{12}$. La iglesia es citada como beneficiaria de las mandas testamentarias del obispo Guisad en 952 y del conde Borrell II en 993, mientras en documentos de 1003 era denominada como sancti Petri de ipsa Sede ${ }^{13}$. De lo hasta ahora expuesto lo que se extrae a ciencia cierta es que, en el siglo X, la Seu d'Urgell ya contaba con un conjunto de al menos dos iglesias. En la de Santa María pudo ubicarse un baptisterio dedicado a San Juan, si aceptamos por válida la interpretación en este sentido del documento alusivo a una "basílica" del Bautista infra domum sancte Marie.

\section{URGELL II: EL OBISPO ERMENGOL (1010-1035) \\ O LA REDEFINICIÓN DEL CONJUNTO ARQUITECTÓNICO}

A comienzos del siglo XI, la documentación nos guía por las sustanciales transformaciones que se llevaron a cabo sobre el conjunto de iglesias en que se desarrolló Urgel I. Entre 1021 y 1023 se donaba para la construcción de una nueva iglesia, localizada al norte del templo principal, y dedicada a San Miguel y que el testamento del obispo Ermengol reconoce obra propia en 1033. El mismo diploma alude a las obras de ampliación o reconstrucción - como veremos, no está claro- de la catedral de Santa María, que fue consagrada en 1040. En 1036 es citada por primera vez la de Santa Eulalia, ahora vecina de la cabecera catedralicia, y 1045 es la fecha más segura para la iglesia del Santo Sepulcro, sobre cuya posible ubicación por ahora carecemos de evidencias documentales o arqueológicas. Por último, entre 1055 y 1092 se reconstruyó la iglesia de Sant Pere, al sur de la catedral. En resumidas cuentas, en cerca de tres décadas se redefinió por completo todo el conjunto catedralicio, con un total de cuatro iglesias - tres de ellas

\footnotetext{
${ }^{11}$ En paralelo y relacionable con el nebuloso período visigodo de la ciudad, la intervención arqueológica realizada en la iglesita de Santa Eulalia sacó a la luz unos restos para los que se ha propuesto una posible funcionalidad bautismal (ADELL, BESERAN, SIERRA y VILLARÓ, La catedral de la Seu, op. cit., p. 23). Para Vic, CARRERO, La arquitectura medieval al servicio de las necesidades litúrgicas, op. cit., pp. 71-73.

${ }^{12}$ Publ. VillanUeVA, Viage literario, op. cit., X, pp. 59-60 y BARAUT, La data de l'acta de consagració, op. cit., doc. 2 , pp. 118-119; regs. PUIG I CADAFALCH y PUJOL I TUBAU, Santa Maria de la Seu, op. cit., p. 22; BARAUT, Els documents, dels segles IX $i$ X, op. cit., doc. 10, p. 31, e ID., Els documents, dels anys 1093-1100, op. cit., ap. doc. 2, p. 117.

${ }^{13}$ Publ. Pere Pujol I TuBau, Els testaments de tres bisbes d'Urgell, "Butlletí del Centre Excursionista e Vic", 2 (1915-1917), pp. 196-200, 3 (1918-1920), pp. 12-14 y 20-25, reed. en Obra completa, op. cit., pp. 107-116 (doc. I, p. 109); PUIG I CADAFALCH y PUJOL I TUBAU, Santa Maria de la Seu..., op. cit., p. 22; BARAUT, Els documents, dels anys 981-1010, op. cit., docs. 232, 233, 286 y 314, pp. 64, 66, 118 y 145.
} 
documentadas por primera vez en estas fechas - rodeando a la principal de Santa María (fig. 1). Que en buena medida la cronología coincida con el pontificado de Ermengol (1010-1035) es la razón que ha llevado a varios investigadores a considerarle el efectivo transformador de la catedral y su entorno ${ }^{14}$.

\subsection{Sancte Marie Sedis Urgellensis}

Consagrada el 22 de octubre de 1040 en presencia de seis obispos, sabemos muy poco del alcance real de su reconstrucción ${ }^{15}$. Eduard Junyent propuso que la intervención de Ermengol en la Seu se limitó a la remodelación de la cabecera del viejo templo del IX, de forma similar a como el abad Oliba había realizado en Sant Miquel de Cuixà ${ }^{16}$. En realidad, la obra debió ser mayor de lo supuesto hasta ahora ya que, en 1084 -cuarenta años después de la consagración de lo que efectivamente debió ser sólo la cabecera-, se documentan las obras en la galilea, a los pies ${ }^{17}$. ¿De nuevo trabajos de remodelación? Lo que, por el contrario, parece un argumento sólido para cuestionar la construcción de un edificio ex novo es que, a menos de un siglo de su probable finalización, ya se estuvieran planteando su reconstrucción, integral en la catedral que ha llegado a nuestros días.

En cuanto a restos arquitectónicos, una intervención arqueológica sobre el exterior norte de la actual catedral sacó a la luz una estructura de planta casi circular cuyo lado meridional se interna bajo el muro de cierre de la nave septentrional de Santa María. Puestos en relación con la iglesia de Ermengol, se han interpretado como parte de una posible triconque o, quizás, como los cimientos de un edificio similar al cercano monasterio de Sant Serni de Tavèrnoles, caracterizado por las absidiolas que rematan los testeros del

${ }^{14}$ BATlle I GALLART, Els orígens medievals de la Seu, op cit., p. 18; ID., La Seu d'Urgell medieval, op . cit., p. 26; Mathias DELCOR, Ermengol évêque d'Urgetl et son oeuvre (1010-1035) de l'histoire à l'hagiographie, "Les Cahiers de Saint-Michel de Cuxa", 20 (1989), pp. 161-190. Francesc FITÉ I LLEVOT, Consideracions sobre el Romànic en l'àmbit dél Comtat d'Urgell, en "El Comtat d'Urgell', Lleida, 1995, pp. 119-148 (134); Prim BERTRAN I ROIGÉ, Ermengol d'Urgell: l'obra d'un bisbe del segle XI, en "La tranformació de la frontera al segle XII. Reflexions des de Guissona arran del IX centenari de la consagració de l'església de Santa Maria”, ed. F. SABATÉ, Lleida, 2000, pp. 89-132 (122-123), Jeffrey A. BowMAN, The Bishop builds a bridge: Sanctity and Power in the Medieval Pyrenees, "The Catholic Historical Review", LXXXVIII-1 (2002), pp. 1-16, y Francesc FITÉ I LLEVOT, Arnau Mir de Tost i el culte a les relíquies. Un exponent pirinenc en la promoció dels santuaris, "Urgellia”, XVI (2006-2007), pp. 511-549 (519).

${ }^{15}$ BARAUT, Les actes de consagracions d'esglésies, op. cit., doc. 54, pp. 135-138.

${ }^{16}$ Eduard JUNYENT, Catalunya Romànica. L'arquitectura del segle XII, Abadia de Montserrat, 1976, p. 74. A partir del documento, de alusiones posteriores a altares y de la comparación con la arquitectura de su tiempo, se ha propuesto una posible cabecera de cinco ábsides en batería (PUIG I CADAFALCH y PUJOL I TUBAU, Santa Maria de la Seu..., op. cit., pp. 15-16; BERTRAN, Ermengol d'Urgell..., op. cit., p. 123). La cuestión tendría su lógica si nos detenemos en Isidro G. BANGO TORVISO, La part oriental dels temples de l'abat-bisbe Oliba, "Quaderns d'estudis medievals", 23-24 (1988), pp. 51-66

${ }^{17}$ Publ. BARAUT, Els documents, dels anys 1076-1092, op . cit., doc. 997, p. 120, e ID., Els documents, dels anys 1101-1150, op. cit., doc. 1319, p. 147; PUUG I CADAFALCH y PUJOL I TUBAU, Santa Maria de la Seu, op. cit., p. 16. 
transepto $^{18}$. Destaquemos lo difícil de su análisis, ya que la estructura exhumada es de planta casi circular y entesta con el basamento de la iglesia románica; además, se encuentra en una zona cuyos estratos arqueológicos debieron ser muy maltratados tras la elevación en época moderna de la capilla barroca de las reliquias, que finalmente sería derribada a comienzos el siglo $\mathrm{XX}^{19}$.

Volviendo a los testimonios documentales de la Santa María del siglo XI, las alusiones más claras son las referentes a sus distintos altares que, junto a los de las restantes iglesias del conjunto catedralicio, funcionaron como ámbitos legales, para la jura y firma de documentos o para la apertura sacramental de testamentos, siguiendo una amplia tradición tardoantigua recogida en toda Europa ${ }^{20}$. Mientras en otros lugares existieron edificios, altares e incluso relicarios que por una significación singular agruparon este tipo de actos jurídicos, en la Seu d'Urgell o en otras ciudades de los condados, como Vic o Girona, no hubo un altar exclusivo destinado a fines legales, por el contrario, encontramos un buen número de aras de la catedral y su entorno haciendo estas funciones ${ }^{21}$. Contamos con, al menos, diez altares documentados por alusión, dedicados a San Agustín, San Pablo, San Juan, San Justo, San Jorge, el Salvador, San Esteban, San Ermengol, Santiago y el Santo Sepulcro, además del principal dedicado a la Virgen ${ }^{22}$. La mayoría de estas dedicaciones fueron recogidas por la catedral tardorrománica y así son referidas en la documentación del XIII ${ }^{23}$.

\footnotetext{
${ }^{18}$ Joan Albert ADELL, Santa Maria de la Seu d'Urgell. Situació, en "Catalunya Romànica", op. cit., VI, pp. 313-315.

${ }^{19}$ Juan BASSEGODA I NONELL, Proyectos barrocos para la Seu d'Urgell, "Espacio, Tiempo y Forma", Serie VII, Historia del Arte, 3 (1990), pp. 151-180.

${ }^{20}$ Arnold ANGENENDT, 'Cartam offerre super altare'. Zur Liturgisierung von Rechtsvorgängen, "Frühmittelalterliche Studien", 36 (2002), pp. 133-158.

${ }^{21} \mathrm{La}$ ley 19 de la tercera partida alfonsí se dedicaba en extenso a legislar los juramentos sobre altares, cruces y otros elementos de culto litúrgico, que tuvo su primer intento de derogación en la ley de Oña de 1498. Y digo primero porque de la costumbre aún dieron fe Isidoro Bosarte y Richard Ford cuando tras sus respectivos viajes por España -durante la segunda mitad del siglo XVIII Bosarte y Ford entre 1833 y $1836-$, se hicieron eco de tres iglesias juraderas castellanas donde se acostumbraba a abjurar poniendo las manos sobre altares y cuerpos santos: el relicario de San Isidoro de León, el bujo de San Vicente en un lateral de su monumento abulense y el cerrojo del Cid en Santa Gadea de Burgos (Isidoro BOSARTE, Viaje artístico a varios pueblos de España con el juicio de las obras que a las tres nobles artes que en ellos existen y épocas a que pertenecen, I, Madrid, 1807, pp. 248-250 Richard FORD, A handbook for travellers in Spain, $3^{\mathrm{a}}$ ed., Londres, 1855, pp. 551 i 748 y 848; para el 'agujero de las juras' de Avila. Daniel RICO CAMPS, El Románico de San Vicente de Avila (Estructuras, imágenes, funciones), Murcia, 2002, p. 311).

${ }^{22}$ Es posible que un altar de San Marcos, sobre el que se juraba en 1048, también perteneciera a la catedral, uno de cuyos arcedianos aparece como testigo del mismo documento (publ. BARAUT, Els documents dels anys 1036-1050, op. cit., doc. 619, p. 142). Lo mismo ocurre con el de Santa Cruz, con referencias a partir de 1178 , pero sin quedarnos claro si ya se encontraba en el edificio inciado por el obispo Ot.

${ }^{23}$ Entre los de Santa María, Santes Creus, Sant Ermengol, Sant Ot, Sant Pau, Sant Andreu, Sant Joan, Sant Jordi, Santa Margalida, Santa Caterina o el Salvador, refundado bajo la torre norte de la catedral por el obispo Pere d'Urtx (PUIG I CADAFALCH y PUJOL I TUBAU, Santa Maria de la Seu, op. cit., p. 81; C. BATLLE I GALLART, La Seu d'Urgell a la segona meitat del segle XIII, segons els testaments, "Urgellia”, 3 (1980), pp. 369-417 -p. 385-).
} 
En 1033, el testamento del obispo Ermengol insiste en el carácter del altar mayor como marco legal ${ }^{24}$. En él debía colgarse el yelmo del caballero Guillem, según requería en su rica voluntad testamentaria en $1064^{25}$. El altar de San Agustín se documenta en 1017, con la publicación del testamento de doña Sancha d'Urgell en el espacio dedicado al santo cuius altarium situm est sub pinnaculum sancte Marie Sedis Orgillensis ${ }^{26}$. Lo mismo ocurría con el altar de San Pablo en 1058, 1061, 1065 o 1068, localizado intra domum Sancte Marie Sedis y receptor de donaciones, o el de San Juan en $1088^{27}$. En 1079 recibía donación el altar de San Justo, localizado en el interior de la catedral $^{28}$, si bien no nos queda claro en absoluto si se trata de la misma advocación a la que dos años después era entregada una cantidad ad opera, junto a otras dedicaciones como el Salvador y las seguras iglesias de San Pedro y San Miguel $^{29}$. El altar de San Ermengol es citado por primera vez en 1044, aunque la advocación al Ermengol santo se documente desde 1041 y en un estado de semi cotitularidad con la catedral y su canónica, al menos en las décadas centrales del siglo XI, convertido en convencionalismo documental que se repite con escasas variaciones en diplomas desde 1063 a $1118^{30}$. En 1051, el testamento de Arnau Salla lo hacía beneficiario de una donación destinada a su tabula, junto a la de Santa María de la Seu ${ }^{31}$. En un par de documentos de 1073 y 1074, de manera indirecta, se cita el Sanctum Ermegaudum vultus en cuyas proximidades se encontraba el altar de San Esteban de la catedral, altar que, por cierto, debe ser el mismo a cuya obra se donaba en 1058 y sobre el que se juraba en $1104^{32}$. En 1075, recibía una donación ad opera, sin mayores complicaciones ${ }^{33}$, mientras en 1084 Estefanía entregaba dos anillos de oro para la realización de su tabula ${ }^{34}$. El altar de

\footnotetext{
${ }^{24}$ Publ. BARAUT, Els documents, dels anys 1010-1035, op. cit., doc. 463, p. 166. En esta función también se documenta en el siglo XIV, cuando el obispo Galceran de Vilanova donaba a șu cabildo el misal iluminado que hoy nos há llegado (publ. PUJOL I TUBAU, Els dos missals mixtos, op. cit., p. 85).

${ }^{25}$ Publ. BARAUT, Els documents, dels anys 1051-1075, op. cit., doc. 755, p. 125.

${ }^{26}$ Publ. ID., Els documents, dels anys 1010-1035, op. cit., doc. 348, p. 59.

${ }^{27} \mathrm{Publ}$. ID., Els documents, dels anys 1051-1075, op cit., docs. $710,734,772$ y 816, pp. 85, 105, 140 y 177, e ID., Els documents, dels anys 1076-1092, op. cit., docs. 994, 1044y 1048 , pp. 117, 166 y 169.

${ }^{28}$ Publ. ID., Els documents, dels anys 1076-1092, op. cit., doc. 927, p. 60.

${ }^{29}$ IBID., doc. 959 , p. 88

${ }^{30}$ Publ. BARAut, Els documents, dels anys 1036-1050, op. cit., docs. 540, 566, 572 y 574 pp. 75, 96, 101 y 103; ID , Els documents, dels anys 105i-1075, op. cit., docs. 649, 650, 744 $822,837,839$ y 842, pp. 35, 36, 114, 182, 193, 196 y 199; ID., Els documents, dels anys 1076 1092 , op. cit., docs. 916,1008 y 1081, p. 48, 129 y 198, e ID., Els documents, dels anys 11011150 , op. cit., docs. 1258 y 1304 , pp.'89 y 133 .

${ }^{31}$ Publ. BARAUT, Els documents, dels anys 1051-1075, op. cit., doc. 647, p. 33.

${ }_{32}^{3}$... remaneat ad Sancto Stephano, qui est prope Sanctum Ermegaudum vultus in ecclesia Sancte Marie (publ. BARAUT, Els documents, dels anys 1051-1075, op cit., docs. 855 y 863 , pp 211 y 217); ad Sancto Stephano solidos III ad ipsa opera (IBID., doc. 703, p. 80). ... super altari Sancti Stephani (ID., Els documents, dels anys 11101-1150, op. cit., doc. 1215, p. 45).

${ }^{33}$ Publ. Domènec SANGÉS, Recull de documents del segle XI referents a Guisona i la seva plana, «Urgellia», 3 (1980), pp. 195-305 (doc. 37, pp. 254-256).

${ }^{34}$ Publ. BARAUT, Els documents, dels anys 1076-1092, op. cit., doc. 997, p. 120.
} 
Santiago es citado junto al de San Juan en 1059 y fue escenario de varias publicaciones sacramentales de testamentos entre los siglos XI y XII ${ }^{35}$. Del altar del Sepulcro trataré en el apartado dedicado a la iglesia que, bajo la misma advocación, fue fundada junto a la catedral a comienzos del siglo XI.

Por último, me gustaría llamar la atención sobre un elemento bien documentado en el edificio del siglo XI: la galilea. Según vimos, en 1084 se hacía una donación de dos sueldos ad opera galilee Sancte Marie y, en 1119, acogía una declaración notarial realizada por una tal Ermengarda: ante Sancte iam dicte Marie galileam ${ }^{36}$. No parece muy arriesgado relacionar las noticias de finales del siglo XI y comienzos del XII con un macizo occidental a la manera de los estudiados por Francesca Español para las catedrales de Barcelona, Girona y $\mathrm{Vic}^{37}$.

Las noticias al respecto no finalizan en el siglo XI. En 1211 era utilizada como elemento delimitador de una casa a construir por A. d'Archavell, obrero de la catedral: locum quemdam in galilea coram ecclesia beate Marie ad faciendam domum. El terreno lindaba con la propia galilea por dos lados, con un muro y con el obrador de la catedral: Afrontat dictus locus, in una parte in muro, de alia in operatorio beate Marie a Johanne de Ceritania dato, de duabus partibus in galilea ${ }^{38}$. ¿Se trataba de la galilea de la catedral del siglo XI, aún en pie durante el proceso de finalización del edificio que la sustituyó? Podría ser, ya que de lo que sí estamos seguros es de que la iglesia tardorrománica no tuvo macizo occidental y sí una estructura porticada a los pies que, además de funcionar como espacio de recepción, se dedicó a acoger los cuerpos que no podían pagarse la sepultura en el interior del templo $o$ en el claustro ${ }^{39}$. Esta zona fue muy transformada durante las primeras décadas del siglo XVI. En 1555 y como continuación del proceso de limpieza y liberación de la catedral y su entorno, el cabildo ordenaba que se derribaran los pórticos - cuberts - y casas que se situaban entre la fachada occidental de la iglesia y la casa del mestre Menaut. En 1577, siguiendo el ejemplo de otras catedrales cuyas puertas y entradas estaban limpias y decorosas, se decidió prohibir los enterramientos en el pati de la porta maior, espacio de indudable-

${ }^{35} \mathrm{Publ}$. ID., Els documents, dels anys 1051-1075, op . cit. docs. 712 y 771, pp. 87 y 139, y SANGÉS, Recull de documents, op. cit., doc. 27, doc. 245 ; BARAUT, Els documents, dels anvs 1101-1150, op cit., docs. 1242 y 1289, pp. 70 y 117; ID., Els documents, dels anys 1191-1200, op. cit., doc. 15 , p. 86.

${ }^{36}$ Publ. BARAUT, Els documents, dels anys 1076-1092, op cit., doc. 997, p. 120, e ID., Els documents, dels anys 1101-1150, op. cit., doc. 1319, p. 147; PUIG I CADAFALCH y PUJOL I TUBAU, Santa Maria de la Seu, op. cit., p. 16.

${ }^{37}$ Francesca ESPAÑoL, Massifs occidentaux dans l'architecture romane catalane, "Les Cahiers de Saint-Michel de Cuxa", XXVII (1996), pp. 57-77. y, aludiendo a la Seu, ID. "L'escultura románica catalana en el' marc dels intercanvis hispanollenguadocians, en "Gombau de Camporrells, bisbe de Lleida a l'alba del segle XIII", eds. I. G. Bango y J. J. Busqueta, Lleida, 1996, pp. 43-81 (41).

${ }^{38}$ Publ. Puig i Cadafalch y Pujol i Tubau, Santa Maria de la Seu, op. cit., p. 74.

${ }^{39}$ Ibidem. 
mente debió resultar de la supresión de los pórticos que lo ocupaban hasta veintidós años antes ${ }^{40}$.

\subsection{Sanctus Petrus de Sede}

Si la vimos documentada desde el siglo X, la iglesia de Sant Pere ha permanecido en el entorno catedralicio hasta nuestros días (fig. 2) aunque, como veremos, reconsagrada a San Miguel para recoger una de las advocaciones que, en la Baja Edad Media, fueron reunidas desde edificios independientes hasta las dos iglesias en que terminó reduciéndose el conjunto catedralicio. Desde mediados del siglo XI se sucedieron las mandas ad opera - una a su cubierta y otra al campanario-, parece que en una natural campaña reconstructiva documentada entre 1055 y $1092^{41}$. A estas fechas respondería el edificio conservado en la actualidad, a pesar de la radical restauración a la que se vio sometido en los años setenta del siglo XX, cuando prácticamente se reconstruyó su nave para uniformarla la cabecera, eliminando los cambios de fábrica que describió Puig i Cadafalch ${ }^{42}$. Se trata de una iglesia de nave única cubierta con madera, cabecera triabsidada y abovedada, decorada al exterior con arcuaciones lombardas y en cuya capilla mayor estuvieron la Maiestas y el Apostolado con la Virgen, hoy conservados en el Museu Nacional d'Art de Catalunya ${ }^{43}$. Cabe destacar que su puerta de ingreso original se encontraba abierta en su fachada norte - la hoy practicable en la sur es moderna-, es decir, afrontada con la catedral, en un diálogo litúrgico entre ambas iglesias del que nos ocuparemos después. En 1097, el levita Esteve donó una importante colección de libros de culto y una serie de bienes con destino a la elaboración de un cáliz para su tesoro, ad celebranda divina misteria ${ }^{44}$. En 1114, recibía cien sueldos para un paño de seda y, entre 1116 y 1119, se

\footnotetext{
${ }^{40}$ Las noticias sobre las obras del siglo XVI en PuIG I Cadafalch y Pujol I Tubau, Santa Maria de la Seu, op. cit., pp. 84 y 86.

${ }^{41}$ BARAUT, Els documents, dels anys 1051-1075, op. cit., docs. 685, 697, 710, 712, 831 y 873 pp. 67, 77, 86, 8, 189 y 225; ID., Els documents, dels anys 1076-1092, op. cit., docs. 959 1089 y 1092, pp. 88, 207 y 209. Alude a esta profusión documental Maria Luïsa CASESI LOSCOS, Sant Miquel de la Seu d'Urgell (abans Sant Pere). Història, en "Catalunya Romànica", op. cit., VI, p. 362. Ya en 1010 en obispo Sal la le dejó una silla de montar cuyo valor se destinaría a su cubrición, suponemos que en obras de mantenimiento (publ. PUJOL I TUBAU, Els testaments de tres bisbes op. cit., doc. II, p. 111; BARAUT, Els documents, dels anys 981-1010, op. cit., doc. 314, p. 145; PUIG I CADAFALCH y PUJOL I TUBAU, Santa Maria de la Seu, op. cit., p. 24).

${ }^{42}$ Gabriel LÓPEZ COLLADO, Ruinas en construcciones antiguas, Madrid, 1976, pp. 206-207, y ADELl, BESERAN, SIERRA y VILlaró, La catedral de la Seu..., op. cit., pp. 39 y 260. Si Puig veía al menos dos fases constructivas (Josep PUIG I CADAFALCH, Antoni DE FALGUERA Y SIVILLA y Josep GODAY Y CASALS, L'arquitectura romànica a Catalunya, 3 vols., Barcelona, 1909, reed. facs. Barcelona, 2001, II, p. 248), la información proporcionada por las posteriores restauraciones llevan a J.-Ã. Adell a señalar una estructura unitaria (Joan Albert ADELL, Arquitectura. Sant Miquel de la Seu d'Urgell (abans Sant Pere), en "Catalunya Romànica", op. cit., VI, pp. 362363, y AdELl, BeSERAN, SIERRA y VILlaRO, la catedral de la Seu, op. cit., p. 42). Sobre la restauración de Sant Pere y el Museu Diocesà urgelés, Lluís M. VIDAL İ ARDERIU, Jordi BERNADÓ, y Anna VIDAL I LARRIBEAU, Lluís M. Vidal i Árderiu, Girona, 2002, pp. 20-23.

${ }^{43} \mathrm{Su}$ iconografía ha sido interpretada desde la reforma gregoriana y la vita apostolica del clero por Anke WUNDERWALD, Les peintures murales de Saint-Pierre de la Seu d'Urgell et leur environnement liturgique, "Les Cahiers de Saint-Michel de Cuxa", XXXIV (2003), pp. 99-114.

${ }^{44}$ BARAUT, Els documents, dels anys 1093-1100, op. cit., doc. 1147, p. 76.
} 
renovaba su mobiliario litúrgico con la restauratione de sus tabule y pro opus cimborio $^{45}$. El funcionamiento de Sant Pere era responsabilidad del propio cabildo y tendremos que esperar hasta 1119 y 1134, para encontrar una primera referencia a su personal con Bernat, sacerdoti Sancti Petri, y Ponç, presbiteri Sancti Petri, de cuya continuidad es testigo Martini, capellani Sancti Petri que aparece firmando un documento de $1195^{46}$.

La publicación sacramental del testamento del obispo Ermengol en 1035 aporta novedades sobre San Pedro. Así, el altar sobre el que se realizó el acto legal era el de San Pablo, que el documento reconoce situado en el atrio de la iglesia: ... et per hunc locum venerationis sancti Pauli apostoli cuius altare situs est in atrium Sancti Petri apostoli intus in Sede Vicco ${ }^{47}$. Por 'atrium' debe entenderse todo el conjunto eclesial, siguiendo una vieja costumbre que compartía vocablo con una estructura porticada o con el contorno de la iglesia, en un cultismo digno del entorno cultural de Ermen$\mathrm{gol}^{48}$. El sentido de nuestro atrium es aclarado sólo dos años después, cuando el altar de San Pablo en San Pedro es aludido como situm est in ecclesia sancti Petri, mientras en 1182 la referencia continuaba siendo al altare beati Pauli quod est situm in ecclesia Sancti Petri ville Sedis ${ }^{49}$. Todavía en 1380 y después de cambiada la advocación del templo a San Miguel, el altar de San Pablo servía como escenario de la venta de un misal que terminaría siendo el utilizado por la congregación de beneficiados de la catedral ${ }^{50}$. Sólo a mediados del siglo XI, en 1049, encontramos una alusión al altar de San Pablo infra ecclesia Sancte Marie Sedis indicando, muy posiblemente, una doble advocación de altares entre la catedral y Sant Pere ${ }^{51}$. Un segundo altar de la iglesia aparece documentado en 1041, 1044 y 1050 como ámbito de juramentos y actos judiciales, refrendados super altare Sancti Andree qui est situs infra domum Sancti Petri ${ }^{52}$. Ambos altares de San Pablo y San Andrés hicieron proponer a Puig i Cadafalch que las dedicaciones de las tres capillas de la cabecera fueran las de los tres Apóstoles, algo que refrenda la oración cantada en su interior durante las procesiones de las letanías documentadas en el siglo XII, consagrada a la intercesión de San Pedro, San Pablo y San Andrés, las

\footnotetext{
${ }^{45}$ ID., Els documents, dels anys 1101-1150, op. cit., docs. 1283, 1297 y 1313, pp. 112, 125 у 140 .

${ }^{46} I$ Ibid., docs. 1314 y 1436, pp. 142 y 248; ID., Els documents, dels anys 1191-1200, op. cit., doc. 1876, p. 45.

${ }^{47}$ ID., Els documents, dels anys 1010-1035, op. cit., doc. 478, p. 177.

${ }^{48}$ Rafael PUERTAS TRICAS, Iglesias hispánicas (siglos IV al VIII). Testimonios literarios, Madrid, 1975, pp. 86-87.

${ }^{49}$ Publ. BARAUT, Els documents, dels anys 1036-1050, op. cit., doc. 499, p. 38; ID., Els documents, dels anys 1151-1190, op. cit., doc. 1769, p. 282 .

50 “....in ecclesia sancti Michaelis celebrandi in altari sancti Pauli”, publ. Pere PUJOL I TUBAU, Els dos missals mixtos de la Seu d'Urgell, "Butlletí del Centre Excursionista de Vic", 2 (19151917), pp. 49-55, reed. Obra completa, op. cit., pp. 81-86 (83).

${ }^{51}$ Publ. BARAUT, Els documents, dels anys 1036-1050, op. cit., doc. 628, p. 150.

${ }^{52} \mathrm{Publ}$. Ibid., docs. 539, 580 y 636, pp. 74, 108 y 157, e ID., Els documents, dels anys 1093 1100 , op. cit., ap. doc. 27 , p. 143 . En la documentación posterior se pierden las noticias, a excepción de una difícil de 1106 en la que se donaba a San Andrés una libra de cera anual, sin mayores aclaraciones (ID., Els documents, dels anys 1101-1150, op. cit., doc. 1233, p. 61).
} 
mismas advocaciones que se recogen en las preces y plegarias rezadas mientras se incensaban sus altares ${ }^{53}$.

\subsection{Sanctus Michael de Sedis}

Entre 1021 y 1023 encontramos el primer registro referente a la tercera iglesia del conjunto: San Miguel. Se trata del testamento del clérigo Vives, redactado antes de partir en peregrinación a Tierra Santa, que legaba una manda a la iglesia en el momento en obras - ad opera sancti Michaelis - ${ }^{54}$. Efectivamente, el templo estaba construyéndose por voluntad del obispo gobernante Ermengol, como ahora veremos. En 1033, el prelado testó mediante un interesantísimo documento que, en muchos sentidos, es el detonante de buena parte de los problemas que se nos plantearán más adelante. El grueso de la donación se dividía entre un primer legado ad iam dicta opera sancte Marie Sedis, y un segundo dedicado a la iglesia de sancto Michaele archangelo, que el mismo prelado reconocía haber construido en la ciudad: quem ego miser et pecator hedificavi in Sede Vico. A renglón seguido, Ermengol hacía donación a la canónica de Santa María de la Sede, a la que además exhortaba a la vida comunitaria: et vivant cotidie in comunia in servitio sancte Dei Genitricis ${ }^{55}$. Sólo cuatro años más tarde, el 19 de mayo de 1037, se entregaba una donación que debía repartirse entre Santa María de la Sede y el que es reconocido como monasterio de San Miguel, sito junto a la catedral: ad Sancto Michael cenobii, qui est prope Sancta Maria in ipsa $\operatorname{Sede}^{56}$. En un testamento de 1053, fue favorecido con mandas que lo definen como institución independiente, al igual que en donaciones de 1055, 1058, 1063 y 1064 en las que se le equiparaba a la iglesia de San Pedro ${ }^{57}$.

De su circunstancia como institución reglar, en 1095, el testamento del sacrista Guillem exhortaba directamente a los clericos qui ibi habitent, vivant in servitium sancti Michaelis sub regula sancti Augustini omni tempore, diferenciándolos de los cunctos statores et (...) missa cantantes de Santa María, es decir, su grupo de presbíteros ${ }^{58}$. A comienzos del siglo XII, Miró Bernat se declara primer abad de San Miguel y era titulado Mironis Bernardi beati Micaeles en 1112, cargo en el que le sigue Bernat Sanç en $1133^{59}$. La trayectoria eclesiástica de ambos personajes nos aclara la importancia del cargo, parte de la estructura capitular. El primero fue limosnero del cabildo,

${ }^{53}$ Gros, La Consueta antiga, op. cit., p. 232.

${ }^{54}$ Publ. BARAUT, Els documents, dels anys 1010-1035, doc. 370, pp. 80-81.

${ }^{55}$ Publ. Ibid., docs. 463 y 478, pp. 164-166 y 177-179.

${ }^{56}$ Publ. ID., Els documents, dels anys 1036-1050, op. cit., doc. 500bis, p. 41.

${ }^{57}$ Publ. ID., Els documents, dels anys 1051-1075..., op . cit., docs. 658, 685, 710, 745 y 755 , pp. 43, 67, 86, 116 y 125; ID., Els documents, dels anys 1076-1092, op. cit., docs. 959 y 1038 , pp. 88 y 161 .

${ }^{58}$ Publ. ID., Els documents, dels anys 1093-1100 op. cit., docs. 1135 y 1142, pp. 60 y 67; PUIG I CADAFÄLCH y PUJOL I TUBAU, Santa Maria de la Seu..., op. cit., p. 19.

${ }^{59}$ Publ. BARAUT, Els documents, dels anys 1101-1150, op. cit., docs. 1242, 1243, 1271 y 1433 , pp. $70,71,102$ y 246. 
apareciendo como testigo en varios documentos, entre los cuales el más significativo es el que, en 1122, le reconoce como Mironem Bernardi, qui tunc prelatus Sancti Michaelis ecclesie erat ${ }^{60}$. El título de prelado no debe extrañarnos. La tradicional división de los cabildos catedralicios entre clero mayor y menor tiene su pecularidad en la Seu. Según destacó Villanueva, desde el siglo XII se constata una división particular entre prelados, canónigos y clérigos, lo que se correspondería en otras sedes con dignidades, canónigos y simples porcionarios ${ }^{61}$. El abadiato de San Miguel era una dignidad capitular y, junto al prior de la canónica de Santa María, recibía el título de decanus dentro del cabildo ${ }^{62}$, por ello el tal Miró Bernat se intitula prelado de San Miguel en 1122. Respecto a Bernat Sanç, llegó a ser arcediano y abad de la canónica de Àger para terminar como obispo de la Seu d'Urgell entre 1141 y $1162^{63}$. La lista de abades de San Miguel continúa con Bernat de Milamur entre 1194 y 1196, sucedido por A(rnau?) de Sagas en este mismo año y, por último, citándose la dignidad en un proceso judicial entre los siglos XII y $\mathrm{XIII}^{64}$. Como bien apuntó Villanueva, poco se deduce del título de abad respecto de una hipotética organización reglar de San Miguel.

La dignidad abacial sobrevivió hasta la secularización del cabildo de Santa María, que podemos situar a finales del siglo XIII. Así, en 1299 se cambió a la dignidad de prior por la de deán y se eliminaron arcedianatos y abadengos, estableciendo otros nuevos ${ }^{65}$. Ahora San Miguel debió pasar a ser una simple parroquia de la ciudad, con su propio cementerio, documentado en $1287^{66}$. En 1364 se produjo su definitiva desaparición con el traslado a su interior del convento dominico hasta entonces extramuros y la transferencia de su advocación a la vieja iglesia de San Pedro, que a partir de este momento estuvo dedicada al Arcángel. El cambio fue motivado por la voluntad de fortificación de la ciudad y el eventual encastillamiento que pudiera sobrevenir por un enemigo en el convento extramuros, factor que conllevó su derribo inmediato al traslado de su comunidad ${ }^{67}$. Los documentos sobre la mudanza y llegada de los dominicos son taxativos al citar a San Miguel como iglesia parroquial $^{68}$, estatus que, según decía, adquirió con la secularización del clero de la catedral. En este preciso momento de dignidad abacial en el cabildo

${ }^{60}$ Ibid., doc. 1333, p. 162. ${ }^{61}$ La peculiaridad, al parecer, la compartió con la catedral de Vic y con la canónica de
Cardona (VILLANUEVA, Viage literario, op. cit. IX, pp. 197-203; tambiên Cebrià BARAUT, El bisbat d'Urgell (segles IX-XIII), en "Catalunya Romanica", op. cit., VI, pp. 43-48, 54, 71-74, reed. en Església i Bisbat d'Urgell, op. cit., pp. 124-140, en particular, pp. 136-137).

${ }^{62}$ VillanueVA, Viage literario, op. cit., X, pp. 68-69.

${ }^{63}$ Francesc FITÉ I LLEVOT, Reculls d'història de la Vall d'Ager. Període Antic i Medieval, Àger, 1985, y Cebrià BARAUT, Jesús CASTELLS, Benigne MARQUÉS y Enric MOLINÉ, Episcopologi de l'Església d'Urgell, La Seu d'Urgell', 2002, pp. 48-49.

${ }^{64}$ BARAUT, Els documents, dels anys 1191-1200, op. cit., docs. 1869, 1876, 1878, 1879, 1880

y 1883 , pp. 34, 43, 46, 48 y 50 y ap. 74 , p. 125 .

${ }^{65}$ VIllanueVA, Viage literario, op. cit., X, p. 108-109.

${ }^{66}$ BATLle, La Seu d'Urgell a la segona meitat, op. cit., doc. 3, p. 404.

${ }^{67}$ Puig i Cadafalch y Pujol i Tubau, Santa Maria de la Seu, op. cit., pp. 19-20.

${ }^{68}$ VILlanueVA, Viage literario, op. cit., XI, doc. XXXIII, pp. 241-245. 
catedralicio pasó a simple párroco, haciéndose cargo de la nueva San Miguel en San Pedro ${ }^{69}$. Bajo la responsabilidad del abad de San Miguel estaba su capellán, según delata la confirmación a Ramon de Boixadera de las posesiones del cargo en 1195, posesiones que, por cierto, incluían bienes en el entorno de la iglesia y sus inmediaciones, vecinas a la entrada y los muros del palacio que, parece, debe referirse a la residencia episcopal urgelitana ${ }^{70}$. Dicho capellán se encargaría de las fundaciones funerarias que, en 1187, sabemos que estaban instituidas en la iglesia ${ }^{71}$.

De la vieja fábrica sabemos que debía contar al menos con tres altares dedicados a los Arcángeles, según la información recogida en la Consueta del siglo XII, en la que se refieren las oraciones a San Miguel, San Gabriel y San Rafael rezadas en su interior ${ }^{72}$. A comienzos del siglo XV, el obispo Galceran reconocía los derechos parroquiales del convento, recopilando la información sobre la entrega de la vieja iglesia a los frailes de Santo Domingo en la segunda mitad del XIV. Siguiendo el interesante diploma, los frailes habían ocupado la iglesia, cementerio, hospital, casas y patios que pertenecían a un San Miguel secularizado y allí habían edificado allí su iglesia, refectorio, dormitorio, claustro,.$^{73}$.

\subsection{Sancta Eulalia}

Considerada una posible fundación privada del siglo X, Santa Eulalia (fig. 3) es documentada por primera vez en 1036 con la publicación del testamento del clérigo Guisard, realizada en Sancta Eulalie cuius baselica sita est in ipsa Sede supra cuius sacro altario et ara posita ubi has condiciones manus nostras tenemus et iurando contangimus ${ }^{74}$. Tuvo un notable uso como ámbito juratorio, haciendo uso de fórmulas diplomáticas que varían escasamente: ...locum veneracionis Sancte Eulalie cuius baselica sita est in ipsa Sede, ... Sancte Eulalie que sita est ecclesia iuxta edis Sedis Vici o supra altare Sancte virginis Eulalie, quod est situm intra satis parvam ecclesiolam que est fundata ad Sancte Marie Sedis obcedam ${ }^{75}$. La responsabilidad sobre Santa

\footnotetext{
${ }^{69} I b i d .$, XI, pp. 121-122.

${ }^{70}$ Publ. BARAUT, Els documents, dels anys 1191-1200, op. cit. doc. 1876, pp. 43-44. Además de éstas también se aludía a un huerto de San Miguel en 126 (Ibid., ap. 10, p. 83). El mismo Ramon de Boixadera aparece titulado como capellán de San Miguel actuando de testigo en diversos documentos hasta 1197 (Ibid., docs. 1886, 1887 y 1888, pp. 53-54).

${ }^{71}$ BARAUT, Els documents, dels anys 1151-1190, op. cit., doc. 1824, p. 328.

${ }^{72}$ Gros, La Consueta antiga, op. cit., p. 232.

${ }^{73}$ Publ. Puig i Cadafalch y Pujol i Tubau, Santa Maria de la Seu, op. cit., pp. 20-22.

${ }^{74}$ BARAUT, Els documents, dels anys 1036-1050, op. cit., doc. 495, pp. 34-36, e ID., Els documents, dels anys 1093-1100, op. cit. ap. doc. 24, $\mathrm{p}_{1} 136$.' La fórmula se repite en 1042 con el testamento del sacrista Seniofred (Ibid. doc. 26, p. 140). El posible carácter privado de su origen lo apunta BATLLE, Els orígens medievals de la Seu, op. cit., p. 16; ID., La Seu d'Urgell medieval, op. cit., pp. 24-25.

${ }^{75} \mathrm{BARAUT}$, Els documents dels anys 1051-1075, op cit., docs. 662, 755, 776, 838,863, pp 47, 125, 144, 217, 194; ID. Els documents, dels anys 1076-1092, op. cit., docs. 905, 951, 959 $971,1032,1063,1081,1089$, pp. 36, 80, 88 97, 153, 182, 198, 206, etc.; ID., Els documents, dels anys 1093-1100, op. cit., docs. 1117, 1141 y'1142, pp. 42, 65 y 67; ID., Els documents, del's
} 
Eulalia debía caer en miembros del propio cabildo y, así parece recogerse en un documento de 1163 cuando entre los firmantes del escatocolo son referidos los canonici et prepositi Sancte Eulalie ${ }^{76}$. Por fin, desde el siglo XV, Santa Eulalia funcionó como capilla del hospital de la ciudad, sito entre el transepto de la catedral, la iglesia de San Miguel y la propia de Santa Eulalia ${ }^{77}$. También vecino a la iglesia se construyó el ayuntamiento, en proyecto en 1461 y todavía sin construir en 1473, sufriendo un buen número de intervenciones durante la Edad Moderna, hasta su definitiva desaparición parece que en el siglo XVIII ${ }^{78}$.

\subsection{Sanctum Sepulchrum de Sede}

La historiografía sobre la catedral ha recogido la probable existencia de una dedicación al Santo Sepulcro en la misma, ya fuera en el entorno de la iglesia mayor o bien como altar en la galilea de Santa María, siguiendo localizaciones parejas en Barcelona, Girona o $\mathrm{Vic}^{79}$. Como tendremos ocasión de ver, parece que ambas noticias pueden contemporizarse, existiendo un posible altar dentro de la iglesia de Santa María y una iglesia independiente dedicada al Sepulcro en sus inmediaciones. El proceso fue en paralelo a otras dedicaciones como la de San Pablo, con un altar en la iglesia de Santa María y otro en la de Sant Pere.

Las referencias documentales al Santo Sepulcro comienzan en los inicios del siglo XI. En concreto, la primera noticia data del año 1017, con el testamento de la vizcondesa Sancha y su donación al que parece ser un altar ad sanctum Sepulchrum en el interior de la catedral ${ }^{80}$. De hecho, en 1044, el sacerdote Seniofred donaba en testamento una serie de bienes, citándolo al mismo nivel que a San Justo y a San Jorge que, efectivamente, fueron altares

anys 1101-1150, op. cit., docs. 1316, 1440, 1450 y 1451, pp. 144, 251 y 259; ID., Els documents, dels anys 115i-1190, op. cit., docs. 1648 y 1655, pp. 171 y 178; ID., Els documents, dels anys 1191-1200, op. cit., ap. 39, p. 103.

${ }^{76}$ ID., , Els documents, dels anys 1151-1190, op. cit., doc. 1570, p. 95.

${ }^{77}$ Carme BATLlE I GALlART, Les institucions benèfiques de la Seu d'Urgell, "Urgellia", 6 (1983), pp. 285-334 (300-301).

${ }^{78}$ Puig I Cadafalch y Pujol I Tubau, Santa Maria de la Seu, op. cit., pp. 17-18; Pujol I TUBAU, La muralla medieval, op. cit., p. 559 y, sobre todo, RUF y VILLARÓ, L'església de Santa Eulàlia, op. cit., pp. 488-497.

${ }^{79}$ Josep GUDIOL, De peregrins i peregrinatges religiosos catalans, "Analecta Sacra Tarraconensia", VIII (1927), pp. 93-119 (103); ESPANOL, Massifs occidentaux op. cit. p. 72 . Cebrià BARAUT, Pelegrins a Terra Santa de l'antic Comtat d'Urgell, al segle XI, "Ésglésia d'Urgell", 271 (1998), pp. 93-119, reed. en Església i Bisbat d'Urgell, op. cit., pp. 509-513; Antoni BACH I RIU, Pelegrins als grans santuaris medievals, "Boletín de la Real Academia de Buenas Letras de Barcelona", 48 (2002), pp. 547-562 (549), WUNDERWALD, Les peintures murales de Saint-Pierre, op. cit., p. 114; FITE, Arnau Mir de Tost $i$ el culte a les relíquies, op. cit., p. 538, y Francesca ESPAÑOL, L'arquitectura románica, en Francesca ESPAÑL y Joaquín YARZA, El Románico catalán, Manresa, 2007, pp. 30-141 (85). 60.

${ }^{80}$ Publ. BARAUT, Els documents, dels anys 1010-1035, op. cit., docs. 347 y 348, pp. 58 y 
en la catedral ${ }^{81}$. Ahí no queda la cosa. En 1045 y 1051, el Sepulcro volvía a citarse junto a los altares de San Justo y San Jorge, qui sunt siti in ipsa Sede ${ }^{82}$. Por fin, en 1079, el conde Ermengol IV hacía donación a varios altaria sacrata localizados intra Santa María, entre los que se cuenta el del Santo Sepulcro, y en 1081era receptor de varios objetos litúrgicos entre los que se encontraba un leccionario ${ }^{83}$.

Respecto a la iglesia, desde 1045 en adelante, el Sepulcro aparece como espacio independiente y al que se concedían donaciones testamentarias: ad domum Sancti Sepulchri de ipsa Sede ${ }^{84}$. Por primera vez en 1053, el testamento de un tal Oriol sitúa el Santo Sepulcro al mismo nivel que las iglesias mayores del conjunto: Santa María de la canónica, San Miguel y San Pedro $^{85}$. En 1057, antes de iniciar su peregrinación a Santiago de Compostela, Guillem Mir hacía una importante ofrenda al Santo Sepulcro urgelitano, en la que se recogen inestimables datos: en primer lugar, lo tilda de iglesia - ecclesia-, en segundo, reconoce como promotor de la misma a su tío Miro Viven, sacer qui ipsa ecclesia Sancti Sepulchri edificavit. Por último, estipula que sobre su altar debían oficiarse misas por la memoria del ínclito Miró Viven y por la suya propia, utilizando el rico ajuar litúrgico que le dejaba en donación, al que se añadiría un salterio en $1075^{86}$. Finalmente, una donación en 1092, la localizaba junto a la catedral de Santa María de la Seu: ...ecclesie Sancti Sepulcri, que est fundata prope ecclesie Sancte Dei genitricis Marie Sedis Urgellensis ${ }^{87}$.

Las noticias sobre la iglesia continúan más allá del siglo XI. El grueso de la donación testamentaria de Pere de Castelló en 1168 se dedicó a las iglesias de la Seu d'Urgell, citadas en el orden siguiente: Santa María, San Pedro, el Santo Sepulcro, San Miguel, Santa Eulalia, San Ot, San Nicolás y San Fructuoso ${ }^{88}$. En los mismos términos se redactaba el testamento del prepósito Bonet - aunque ahora las beneficiarias de sus bienes eran la obra de

\footnotetext{
81 "ad ipso Sancto Sepulchro et ad Sancto Iusto et ad Sancto Georgio" (publ. BARAUT, Els documents, dels anys 1036-1050, op. cit., doc. 574, p. 103; ID., Els documents, dels anys 1036-

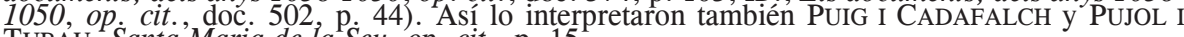
TUBAU, Santa Maria de la Seu, op. cit., p. 15.

${ }^{82}$ Publ. BARAUT, Els documents, dels anys 1036-1050, op. cit., doc. 581, p. 110, e ID., Els documents, dels anys 1051-1075, op. cit., doc. 642, p. 27.

${ }^{83}$ Publ. ID., Els documents, dels anys 1076-1092, op. cit., doc. 927, p. 60; Pere PUJOL I TuBAu, De la cultura catalana medieval. Una biblioteca dels temps románics, "Estudis Universitaris Catalans", 7 (1913), pp. 1-8, reed. Obra completa, op. cit., pp. 47-54'(51).

${ }^{84} \mathrm{Publ}$. BARAUT, Els documents, dels anys 1036-1050, op. cit., doc. 588, p. 118, e ID., Els documents, dels anys 1051-1075, op. cit., doc. 670, p. 55; ID., Els documents, dels anys 1076-1092, op. cit., docs. 951, 974 y 1025, pp. 80-81, 100 y 144; Diplomatari de l'Arxiu Capitular de la Catedral de Barcelona. Segle XI, eds. Josep BAUCELLSI REIG, Àngel FÀBREGA

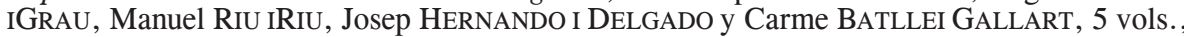
Barcelona, 2006, III, doc. 687, p. 1169.

${ }^{85}$ BARAUT, Els documents, dels anys 1051-1075, op. cit., doc. 658, p. 43.

${ }^{86}$ Ibid., docs. 696, 697 y 873, pp. 75-77 y 225.

${ }^{87}$ BARAUT, Els documents, dels anys 1076-1092, op. cit., doc. 1095, p. 215.

${ }^{88}$ ID., Els documents, dels anys 1151-1190, op. cit., doc. 1622, p. 147.
} 
la propia catedral-, y las iglesias de San Miguel, el Santo Sepulcro, San Pedro y San Nicolás, o en el de Ramon Isarn, en el que se recogen San Pedro, el Santo Sepulcro, San Miguel, Santa Eulalia y San Fructuoso ${ }^{89}$.

Sobre la cronología certera de la iglesia del Sepulcro poco sabemos aunque, si en 1057 Guillem Mir nos informaba de cómo su tío materno la había construido, una diferencia de veinte o treinta años no parece demasiado larga en una línea familiar directa. En cualquier caso, una fecha marco entre las tres primeras décadas del siglo XI parece la más apropiada ${ }^{90}$. Respecto a su organización y mantenimiento, en una donación de 1131 se recoge como responsable de la misma a un Bernardo priori, que debemos identificar con Bernat Arnau, prior del cabildo catedralicio de la Seu en estas décadas del siglo XII ${ }^{91}$. El diploma pone de manifiesto que, efectivamente, la iglesia del Santo Sepulcro era uno de los establecimientos religiosos que dependían directamente del cabildo de la Seu, junto a San Pedro, San Miguel y Santa Eulalia. Por otro lado, los encargados del culto en su interior debían ser miembros del estamento capitular, como aquel Berenguer presbiteri de Sancti Sepulcri referido en 1136 y Arnau Lambard, capellán del Santo Sepulcro y prohombre urgelitano ${ }^{92}$, documentado a mediados del siglo XIII, en una época en la que el edificio debía estar realizando funciones parroquiales como las hacía Sant Miquel, otra de las iglesias del conjunto original. El Sepulcro gozaba de su propio patrimonio según traslucen documentos de la segunda mitad del siglo XII, como la donación de la iglesia de Sant Miquel de la Sentiu y el término del castillo de Taravat qui ecclesiam Sancti Sepulcro Sedis tenuerint, a la par que se registran donativos de ornamentos litúrgicos para su altar, como la de $1288^{93}$.

Quizás el mayor inconveniente sea que, por ahora, desconocemos su ubicación en el entorno catedralicio. A riesgo de pillarme los dedos, creo que

${ }^{89} \mathrm{Ibid}$, doc. 1824, p. 328, e ID., Els documents, dels anys 1191-1200, op. cit., ap. 39, p. 103. De la iglesia de San Fructuoso tenemos la primera mención como beneficiaria de donación en 961 (BARAUT, Els documents, dels segles IX $i X$, op. cit., doc. 140, p. 100), aunque no reaparece como tal hasta la segunda mitad del siglo XII, según vemos, y en el siglo XIII se especifica ubicada en la huerta del Șegre. Ya en el XIII, en la paz firmada entre el obispo Ponc de Vilamur y Roger conde de Foix en 1244 "actum est hoc inter Sedem et Ciuitatem apud Sanctum Fructuosum", publ. Pere PUJOL I TUBAU, Documents en vulgar dels segles XI, XII y XIII, procedents del Bisbat d'Urgell, "Biblioteca Filològica de l'Institut de la Llengua Catalana" (1913), reed. Obra completa, op . cit., pp. 19-38 (29); otros testimonios en BATLLE, La Seu d'Urgell a la segona meitat, op. cit., p. 385. De San Nicolás, situada al norte de la ciudad, sabemos que en el siglo XIII tenía su capellán en Pere de Bellpuig, uno de los notarios de la Seu al igual que Sant Ot, el altar de la parroquia catedralicia situada al sur de la fachada occidenta del templo, cuyo capellán tambiến aparece inmiscuido en asuntos legales de la ciudad (BATLLE, La Seu d'Urgell a la segona meitat, op. cit., pp. 371-372).

${ }^{90} \mathrm{El}$ hecho de que no aparezca referida entre las tres iglesias catedralicias del testamento de Ermengol - Santa María, Sant Pere y Sant Miquel- no debe considerarse un término cronológico, Santa Eulàlia tampoco aparece y sabemos de su segura existencia en estas fechas.

${ }^{91}$ BARAUT, Els documents, dels anys 1101-1150, op . cit., doc. 1413, p. 226. Bernat Arnau aparece documentado como testigo o receptor y administrador de donaciones en varios documentos, v. g. Ibid., doc. 1409, p. 223.

${ }^{92}$ BARAUT, Els documents, dels anys 1101-1150, op. cit., doc. 1451, p. 259; BATLLE, La Seu d'Urgell a la segona meitat, op. cit., p. 380.

${ }^{93}$ BARAUT, Els documents, dels anys 1151-1190, op. cit., doc. 1756, p. 270; ID., Els documents, dels anys 1191-1200, op. cit., doc. 31, p. 98, y BATLLE, La Seu d'Urgell a la segona meitat, op. cit., pp. 404-416. 
lo más lógico pensar que se situara en un arco imaginario al norte del templo principal, entre su fachada oeste y la cabecera, debido a la profusión de edificios frente a su fachada meridional en la que, a la postre, se edificaría el claustro. A mediados del siglo XII, la procesión recogida en la Consueta antigua de la catedral establece un recorrido que va de la iglesia mayor hasta San Pedro, de ésta hasta el Sepulcro y de aquí a la iglesia de San Miguel, pareciendo un recorrido lógico desde San Pedro hasta San Miguel pasando por la fachada occidental de la catedral ${ }^{94}$. Hasta aquí las noticias sobre el Santo Sepulcro. Desconocemos cuándo desapareció, en un momento por ahora indeterminado entre el siglo XIV y comienzos del XV, fechas en que la Consueta Nova de 1418, el Procesionario y el Ordinario de la catedral ya no recogen procesión alguna a la misma como, según veremos, sí se refiere en la Consueta del siglo XII ad ecclesiam Sancti Sepulcri.

\subsection{La canónica}

Las oficinas capitulares se concentraron frente a la fachada meridional de Santa María, ocupando el espacio entre ésta y la iglesia de Sant Pere (fig. 4). La consueta del siglo XII alude a la sala capitular, en la que se leía el calendario, calenda o pretiosa del cabildo, vidas de santos y otros textos ejemplarizantes ${ }^{95}$. Nada sabemos de cómo pudo ser, desaparecida con la reforma de la galería claustral correspondiente en 1601, aunque sí nos consta que el obispo Pere de Urtx (1269-1293) patrocinó unas obras de mantenimiento, entre las que se incluyeron claustro y capítulo ${ }^{96}$. Según la consueta catedralicia, durante la conmemoración de la Ultima cena, el mandato era celebrado en la sala capitular y el refectorio: en la primera el lavatorio de pies del propio cabildo y en el segundo el de los pobres: Post hec fiat mandatum, primo pauperum in refectorio, deinde clericorum in capitulo, et cantentur antifone 'Cena facta' et alie ad sufficiendum ${ }^{97}$. El refectorio es citado además en mandas testamentarias dedicadas a la alimentación de los canónigos, como la que en 1045 destinaba una cantidad al aceite y el pescado que debían tomar durante la Cuaresma, o en los estatutos capitulares de 1161, con el estableci-

\footnotetext{
${ }^{94}$ Puestos a imaginar, aụque sin refrendo arqueológico de ningún tipo, podríamos presuponer que se tratara de un espacio centralizado a imitación del Sepulcro de Jerusalén y en consonancia con otros edificios del contexto europeo y catalán cronológicamente parejos. La bibliografía al respecto es más que importante, aunque aparece recogida en la soberbia sintesis de, Justin E. A. KROESEN, The Sepulchrum Domini through the Ages. Its Form and Function, Lovaina-ParísSterling (Virginia), 2000. Para Cataluña, Jordi VIGUÉ, Les esglésies romàniques catalanes de planta circular i triangular, Barcelona, 1975, y ESPAÑOL, Massifs occidentaux, op. cit., pp. 6770.

${ }^{95}$ Gros, La Consueta antiga, p. 196.

${ }^{96}$ Puig i Cadafalch y Pujol i Tubau, Santa Maria de la Seu, op. cit., pp. 74, n. 2 y 76-78.

${ }^{97}$ Gros, La Consueta antiga, p. 225. Asunto habitual en todas las catedrales y monasterios, como recogí en Eduardo CARRERO SANTAMARÍA, La funcionalidad espacial en la arquitectura del Medievo y las dependencias catedralicias como objeto del estudio histórico-artístico "Medievalismo", 9, 1999, pp. 149-175, en particular, p. 170. Luego, para Vic y Sant Cugat de Vallès, Francesca 'ESPAÑOL, La polifuncionalidad de un espacio retringido. Los usuarios religiosos y la satisfacción de las necesidades comunitarias, en "Claustros románicos hispanos", eds. J. Yarza y G. Boto, León, 2003, pp. 11-29.
} 
miento de las doce preposituras responsables del mantenimiento de la canónica $^{98}$. También era destino de una de las procesiones pascuales referidas en la consueta, durante la que se entonaba el tropo Quem queritis in sepulcro. Por fin, sobre el dormitorio, un testamento de 1065 legaba bienes a su iluminación ${ }^{99}$. Ya en el siglo XII y de forma indirecta, la consueta alude al mismo, del que los canónigos salían al tañido de la campana de los rezos nocturnos a la voz del salmo 24 -Ad te Domine levavi-, entrando después procesionalmente en la iglesia, iniciando la oración canonical Gratias tibi ago, omnipotens Pater ${ }^{100}$.

De dónde se encontraban cada una de estas dependencias tenemos algunas certezas. El capítulo parece que se situó, al menos desde la construcción tardía del claustro, entre el brazo sur del transepto y la iglesia de Sant Pere y, si la localización del dormitorio es una incógnita, al menos el refectorio estuvo en la domus canonicalis paralela a la galería occidental del claustro, muy modificada entre los siglos XIV y XVI y que actualmente aloja el Museu Diocesà d'Urgell. Como documenta Pujol i Tubau, en esta Casa del Capítol se localizó el refectorio de los beneficiados durante la Baja Edad Media; era limítrofe con el palacio episcopal hasta tiempos del obispo Galceran de Vilanova (1388-1415), que lo trasladó hasta su actual ubicación, dejando el antiguo inmueble a la dignidad decanal ${ }^{101}$. La cuestión más interesante a destacar aquí es cómo el claustro actual se debió adecuar a los edificios previos, es decir, a la superficie marcada por las iglesias de Santa Maria y Sant Pere, la canónica a occidente y puede que ya el capítulo al Este, aunque la cronología de las galerías claustrales y la existencia o no de un claustro porticado previo caiga fuera de los límites de este trabajo ${ }^{102}$. Por

\footnotetext{
${ }^{98}$ Publ. VIllanueVA, Viage literario, op. cit., IX, doc. XXVIII, pp. 294-298; BARAUT, Els documents, dels anys 1036-1050, op. cit., doc. 588, pp. 116-118 M. RIU I RIU, Historia. Santa Maria de la Seu d'Urgell, en "Catalunya Romànica", op. cit., VI, pp. 315-326 (325).

99 “...ad ipsa cannonicha de predicta sedis Urgelli ad ipso dormetorio per lumine" (publ. BARAUT, Els documents dels anys 1051-1075, op. cit. doc. 776, p. 144, y PUIG I CADAFALCH y Pujol I TUBAU, Santa Maria de la Seu, op. cit., p. 17, n. 1).

100 "Nocturnis horis, cum audito signo de lecto quisque surrexerit, in primis signum sancte crucis, sub invocatione Sancte Trinitatis, sibi in primat et dicat 'Ad te Domine levavi'. Ingressus vero ecclesiam, cum summa reverentiạ, fundat precem coram Domino, psallens corde quạm ore, ita ut illius vox vicinor sit Deo quam sibi, dicatque hanc orationem 'Gratias tibi ago, omnipotens Pater..." (GROS, La Consueta antiga, op. cit., p. 194).

${ }^{101}$ VIllanueVA, Viage literario, op cit. IX, p. 172; Pere PUJOL I Tubau, Notes $i$ documents sobre la construcción de retaules en l'Alt País d'Urgell, "Homenatge a Antoni Rubió i Lluch. Miscel-lània d'estudis històrics i lingüístics", Barcelona, 1936, II. pp. 436-489, reed. Obra completa, op. cit., pp. 591-611 (594) e ID. L'església de la Pietat, de la Seu d'Urgell, "Analecta Sacra Tarraconensia”, 5 (1922), pp. 331-352, reed. Obra completa, op. cit., pp. 385406, y BARAUT, CASTELlS, MÁRQUÉS y MOLINÉ, Episcopologi de l'Església, op. cit., p. 67. Sobre la entidad arquitectónica y noticias documentales de las casas comunes de los cabildos peninsulares entre los siglos XI y XII, Eduardo CARRERO SANTAMARÍA, Sobre ámbitos arquitectónicos y vida reglar del clero. La canónica de la Seu Vella de Lleida, "Seu Vella. Anuari d'Història i Cultura", 3 (2001), pp. 82-107, e ID., La "vita communis' en las catedrales peninsulares: Del registro diplomático a la evidencia arquitectónica, "A Igreja e o Clero português no contexto europeu”, Lisboa, 2005, pp. 171-194.

${ }^{102}$ En 1135, Guillem Tedball testaba haciendo beneficiarios de sus voluntades a la canónica y a su refectorio, a los presbíteros mayores y menores de la catedral, al Santo Sepulcro y el hospital, al altar mayor y "ad claustrum Sancte Marie", al que corresponderían dos maravedíes y un hórreo (BARAUT, Els documents, dels anys 1101-1150, op. cit., doc. 1445, p. 255).
} 
último, sabemos del primer hospital de la catedral sito junto a su puerta - presuponemos que la occidental-, al que alude en donación el conde Ermengol en 1132 ad hospicium pauperum quod est situm iuxta portas eiusdem sancte Sedis ${ }^{103}$.

\section{LA CATEDRAL Y SUS IGLESIAS. LA CIUDAD DEL SIGLO XI}

Una vez recogidas las alusiones documentales a las iglesias que la Seu d'Urgell albergó allá por el siglo XI, es de ley plantearnos una reflexión sobre el paisaje urbano de este momento. ¿Cómo era el entorno de la catedral y sus iglesias vecinas? Está claro que nada tenía que ver con la realidad actual. No voy a insistir en la cuestión del nacimiento de las más viejas ciudades catedralicias y una disposición urbana que, en algunas ocasiones, tuvo mucho que ver con la regularidad del cabildo, como fue la partición entre ciudad eclesiástica y ciudad civil, ambas envueltas en su propio medio defensivo. De hecho, la refundación de la Seu d'Urgell se hizo alrededor de la catedral, la sede urgelitana como la propia toponimia indica ${ }^{104}$. De todos modos, si queremos tener una imagen aproximada de cuál fue el aspecto de nuestra serie de iglesias, no hace falta irnos muy lejos. En la provincia de Barcelona, el conjunto episcopal de Terrassa es uno de esos ejemplos milagrosos de conservación arquitectónica y urbana, con una cronología temprana, apoyada además por los más recientes estudios (fig. 5). Tres iglesias, un baptisterio, una capilla menor y los restos de un episcopium, con un claro esquema evolutivo desde la inicial basílica, parangonable al que describíamos en Urgel I. La interpretación funcional del conjunto pasa por la de una iglesia reglar, otra iglesia parroquial-episcopal, y una funeraria, a las que se añadieron las restantes edificaciones ${ }^{105}$. Un segundo ejemplo. Hace escasas fechas me detuve en el conjunto de iglesias que terminaron conformando la catedral de San Salvador de Oviedo y los vecinos monasterios benedictinos de San Vicente y San Juan Bautista y San Pelayo. En este caso, se trataba de un complejo con origen en una iglesia de propiedad regia y en su vecina capilla funeraria, que concluirían vertebrando a tres comunidades eclesiásticas - clero de San Salvador y monjes y monjas de San Benito- implicadas en el recuerdo de los reyes de Asturias ${ }^{106}$. Lo mismo ocurrió en Santiago de Compostela alrededor de las reliquias del Apóstol y hasta la definición del complejo catedralicio bajo la autoridad de un cabildo. Si histórica e institucionalmente Oviedo o

\footnotetext{
${ }^{103}$ Publ. BARAUT, Els documents, dels anys 1101-1150, op. cit., doc. 1425, p. 238.

${ }^{104}$ Las diferencias con que la documentación trata el vicus o la civitas Sedis Urgellensis han sido estudiadas en BATLLE, Els orígens medievals de la Seu, op. cit., pp. 16 y 25, e ID., La Seu d'Urgell medieval, op. cit., pp. 19-21 y 34-35.

${ }^{105} \mathrm{M}$. Gemma Garcia Llinares, Antoni A. Moro García y Francesc Tuset Bertran, La seu episcopal d'Egara. Arqueologia d'un conjunt cristià del segle IV al IX, Tarragona, 2009.

${ }^{106}$ Eduardo CARRERo SANTAMARÍA, La 'ciudad santa' de Oviedo, un conjunto de iglesias para la memoria del rey, "Hortus Artium Medievalium", 13, 2007, pp. 375-389.
} 
Compostela sólo comparten con la Seu su final catedralidad, sí participan de un mismo aspecto físico: el de un conjunto de iglesias relacionadas entre sí, aunque manteniendo sus singularidades propias. En Terrassa, la historia discurre en paralelo al tratarse, como en Urgell, de una catedral y sus templos vecinos.

Las cinco iglesias que en las primeras décadas del siglo XI integraron el conjunto catedralicio de la Seu d'Urgell estuvieron reunidas en un medio urbano común: un gran atrio en el que junto a los templos se levantaban edificios de servicios para las comunidades religiosas que se encargaban de los mismos. Además, cada una de las cinco iglesias contó con su atrio particular, entendiendo por tal el dextro que rodeaba a un templo en un número reglado de pasos y que servía, entre otros fines, para dar sepultura a los muertos y gozaba de un estatus jurisdiccional propio ${ }^{107}$. No en vano, en el siglo XIII, los atrios de las cinco instituciones estaban funcionando como lugar de enterramiento de la población urgelitana. El cementerio de Santa María - localizado entre la cabecera del templo y la actual explanada junto a la calle Omscompartía la voluntad de sepelios con el más prestigioso y prohibitivo claustro catedralicio, en buena medida reservado a los propios canónigos y a personajes pudientes. El de Santa Eulalia pasó por una etapa de receso hasta el siglo XIV, cuando se retomaron las voluntades de enterramiento en el mismo, cuestión que se ha explicado mediante las noticias que refieren obras en la propia iglesia y que, quizás, fueron en detrimento de su uso. Mientras, el menor número de intenciones funerarias en el cementerio del Santo Sepulcro -un total de cinco recogidas en los testamentos del siglo XIII, frente a las diecisiete de la catedral, las veintiocho de Sant Miquel o las doce de Sant Pere- ha sido vinculado a las posibles menores dimensiones su cementerio ${ }^{108}$. A comienzos del XVI, aún eran referidos como hitos en la topografía urbana del conjunto el cementerio de la propia catedral, el del Hospital de Santa Eulàlia, el de extranjeros y el ahora llamado de Sant Ot, junto a la fachada occidental de Santa Maria ${ }^{109}$.

Deteniéndonos en otras noticias directas y más tempranas, el atrio de Santa María se documenta en 1065, cuando un tal Guillem pagaba a la catedral el pecado de haber golpeado a Guitard Esclua ante hostium de Sancte Marie,

${ }^{107}$ En un plano general, Isidro G. BANGO TORVISO, Atrio y pórtico en el Románico español: concepto y finalidad cívico-litúrgica "Boletín del Seminario de Estudios de Arte y Arqueología", 40-41 (1975), pp. 175-188, y, centrados en los condados, Víctor FARÍAS ZURITA, La sagrerá catalana (c.1025-c.1200): 'Características y desarrollo de un tipo de asentamiento eclesial", "Studia Historica. Historia Medieval", XI (1993), pp. 81-121, ID., 'Treva et paz tener'. Lá 'sagrera' y la paz de los obispos en la diócesis de Urgell (siglos XI y XII), "Etudes Roussillonnaises", 21 (2005), Le Moyen Age dans les Pyrénées catalanes: Art, culture et société. A la mémoire de Mathias Delcor, ed. Michel ZIMMERMANN, pp. 87-92, y las aportaciones incluidas en Les sagreres a la Catalunya medieval. Jornada d'estudi organitzada per l'Associació d'Historia Rural de les Comarques Gironines, 2000 , eds. Víctor FARÍAS, Raimon MARTí y Aymat CATAFAU, Girona, 2007.

${ }^{108}$ BATLle, La Seu d'Urgell a la segona meitat, op. cit., pp. 382-383 y 416, y RuF y VILlARó, L’església de Santa Eulàlia, op. cit., p. 490. Para los enterramientos claustrales ya en el siglo XIV, PUIG I CADAfAlch y PUJOL I TÚBAU, Santa Maria de la Seu, op. cit., p. 79.

${ }^{109}$ Así lo recoge AltÉS I AgUILÓ en El processoner de la Seu d'Urgell, op. cit., p. 41. 
reconociendo la importancia legal y sagrada de su entorno ${ }^{110}$. Aunque ya en la catedral tardorrománica, en distintas ocasiones el orto beate Marie Sedis es considerado posible lugar de enterramientos si el claustro catedralicio no podía ser utilizado a tal fin, al mismo nivel que la fachada occidental de la catedral, hasta el siglo XVI en que se suprimió dicha función ${ }^{111}$. El cementerio de Sant Pere siguió en funcionamiento durante toda la Edad Media, con una interesante segregación de usos respecto de su entorno, según pone de manifiesto el testamento de Bernat Pere en 1343. En el diploma, el clérigo estipula que el atrio de San Pedro fuera su segunda opción de enterramiento, en el caso de que el cabildo no le permitiera enterrarse en el claustro de la catedral ${ }^{112}$. Dado que el lado norte de la iglesia limitaba con la galería claustral meridional, el cementerio de San Pedro sólo pudo localizarse entre sus fachadas Este y sur, formando parte de la sagrera y de la parroquia. Del dextro de la iglesia del Santo Sepulcro no tenemos noticias hasta finales del siglo XIII, momento en que recibió las cinco voluntades de enterramiento hoy documentadas, mientras el de Sant Miquel aparece referido en 1287, con las tumbas que se ubicaban frente a la portada de la iglesia ${ }^{113}$. En resumidas cuentas, la Seu d'Urgell hacia 1040 debía ser un singular conjunto de edificios funcionalmente independientes pero insertos en un gran atrio rodeado por las casas del personal de la catedral.

\subsection{Los cabildos de la Seu}

Es el personal capitular, precisamente, el que más nos interesará ahora, al tratar de definir la entidad de cada templo y sus responsabilidades. Hemos visto cómo la duplicidad de iglesias de Urgell I fue ampliada a un conjunto de cinco espacios sacros a comienzos del siglo XI. Santa Eulalia y el Sepulcro aquí no nos atañen en tanto y en cuanto fueron fundaciones privadas y quizás marcadas por un origen funerario. Es en San Miguel en donde tendremos mayores problemas. Hasta las primeras décadas del siglo XI, Santa María y Sant Pere podían identificarse como un conjunto catedralicio de dos templos, vecino el uno del otro, al que se unirían el palacio episcopal y la residencia de los canónigos, siguiendo un modelo bien conocido para el resto de Europa. La canónica catedralicia aparece citada desde los primeros documentos del siglo IX. Lógicamente, se situaría en la órbita reformista del concilio de Aquisgrán (816), que reglamentaba la vida comunitaria del clero catedralicio con unos estatutos que, ojo, en ningún momento se convirtieron

\footnotetext{
${ }^{110}$ Publ. BARAUt, Els documents, dels anys 1051-1075, op. cit., doc. 783, pp. 150-151.

${ }^{111}$ Publ. Puig I CAdafalch y Pujol i Tubau, Santa Maria de la Seu, op. cit., p. 79, n. 2. Lo que no nos queda claro si por el huerto de Santa María se entiende alguno de sus exteriores septentrional u oriental o, directamente, el vergel claustral.

${ }^{112}$ "Et eligo meo corpori sepulturam in claustro ecclesie beate Marie Sedis Urgellensis si capitulum mihi me volverit acceptare et si nollet me seu corpus meum inibi acceptare, eligo ipsam sepulturam in cimiterio ecclesie sancti Petri predicti, quam mando fieri honorificenter" (publ. PUIG I CADAFAlCh y PUJOL I TUBAU, Santa Maria de la Seu, op. cit., p. 79, n. 2).

${ }^{113}$ BATLLE, La Seu d'Urgell a la segona meitat, op. cit., doc. 3, y p. 404-416 y RuF y VIllaró, L'església de Santa Eulàlia, op. cit., p. 490.
} 
en regla canonical, a la manera de la de San Crodegango para la catedral de Metz. Los estatutos del concilio de Aquisgrán sólo fueron unas recomendaciones para la vida comunitaria del clero de cada iglesia mayor de una diócesis. Se ha insistido en la ausencia de una vita communis desde la restauración de la sede hasta el comienzos del siglo XI y creo que aquí merece la pena realizar alguna matización. La primera pasa por la real consideración de lo que entendemos por un cabildo catedralicio antes del siglo XI. Puede resultar difícil que, acostumbrados a ver capas de coro, grandes sillerías y cuantiosos cabildos bajomedievales y modernos, percibamos lo 'modesto' del clero capitular altomedieval, que era reducido y muy alejado de grandes comunidades: un grupo de clérigos que acompañaban al prelado y compartían el trabajo de la diócesis y un segundo grupo que se constituía en comunidad monástica. Ambos grupos son lo que terminarían generando la división entre dignidades y canónigos y, en éstos últimos, entre cabildo mayor y cabildo menor. En los conjuntos de iglesias dobles, una de las dos era la dedicada al obispo, su clero y el culto parroquial; la otra, la destinada a la comunidad que realizaba vida comunitaria. De entre los muchísimos ejemplos posibles, creo que los usos del arzobispado milanés son los más explicativos, a pesar de presentar una interesante peculiaridad propia. El clero de las sedes de la archidiócesis se dividía en los tradicionales dos grupos citados -episcopal/parroquial y monástico, cardinalis y decumani - con sus respectivas iglesias en conjuntos catedralicios desdoblados. La singularidad a la que aludíamos es que, en función del año litúrgico, ambas comunidades intercambiaban su iglesia. Así, si el Tiempo ordinario era oficiado en una de las dos, los Tiempos fuertes lo eran en la otra, con un majestuoso ceremonial de traslación entre templos de la comunidad reglar y la episcopal ${ }^{14}$.

Creo que desde la primera anotación documental a los canonici de la Seu d'Urgell en 833, podemos pensar en la existencia de un pequeño cabildo rodeando al prelado. Lo mismo ocurre con el documento de la restauración de la canónica por el obispo Ermengol el 18 de noviembre de 1010, cuando invocaba a la figura de Luis el Piadoso como reformador de la vida comunitaria del clero - gloriosissimum Lodovicum imperatorum auctorem dispositoremque ese vite kanonice - y al flaco favor que los nobles y poderosos habían hecho a su desarrollo ${ }^{115}$. No hay la menor duda de que se trataba de una inicial canónica que, con el tiempo, había ido relajando sus costumbres y necesitaba de una reforma. Además de la serie documental que, desde el siglo IX, alude a los canónigos de la Seu en numerosas ocasiones, para los más escépticos, la idea del pequeño grupo de canónigos viviendo alrededor del obispo aparece en dos claros testimonios urgelitanos. El primero es de tiempos del obispo Sal·la (981-1010), cuando el prelado hacía testamento donando su cama al tesorero

\footnotetext{
${ }^{114}$ CARRERO, La arquitectura medieval al servicio de las necesidades litúrgicas, op. cit.

${ }^{115}$ Publ. BARAUT, Els documents, dels anys 1010-1035, op. cit., doc. 315 p. 29. Nos recuerda la importancia de la cita al Emperador RIU, Història. Santa Maria de la Seu, op. cit., p. 322 .
} 
Bonhome ${ }^{116}$. La acotación al lecto in quo iacet ad sancta Maria no debe ser interpretada como referente al trabajo de un simple sacristán cuidando los bienes del templo y durmiendo en él, sino al de un efectivo tesorero en el entorno del prelado y que residía en el episcopio alrededor de la catedral. El segundo es del obispo Ermengol quien, siguiendo los propósitos e intenciones de su predecesor Sal·la, refundaba la canónica de la catedral de Santa María en 1010, aludiendo a la misma en varias ocasiones como in meo episcopio ${ }^{117}$. Además, indiquemos que los documentos del siglo $\mathrm{X}$ refieren a cinco arcedianos y un máximo de doce canónigos actuando como testigos, un número bien alejado de los grandes cabildos de la Edad Media central, como los cuarenta que instituiría el obispo Eribau en la consagración de Urgell II ${ }^{118}$. ¿Y de la comunidad monástica? Lejos de estatutos capitulares y reformas puntuales donde este tipo de corporaciones son citadas, es difícil encontrar alusiones documentales a la misma más allá de algún escatocolo. En nuestro caso, un documento de 949 podría ser interpretado en este sentido. Se trata de la donación del presbítero Dacó a Santa María de la Seu y a las iglesias allí construidas - qui ibidem sunt constructas - , en que se alude a su personal en los siguientes términos: pontifices, presbiteri, chanonaci vel monachi servientes domum sancta Maria vel ipsas ecclesias in sua subdictione presentes et futuri ${ }^{119}$. ¿Puede tratarse de la alusión a los monjes catedralicios, que encontramos en otras catedrales peninsulares? Es posible aunque, como canónica de sesgo aquisgranés, la Seu debía contar con la tradicional división capitular entre alto y bajo clero, los canónigos sine proprio y los cum proprio, los que vivían en comunidad y los que podían no hacerlo ${ }^{120}$. Siguiendo las preclaras palabras de Vicente de la Fuente, ofrecía el raro contraste de los canónigos que vivían sin propiedad alguna y los que conservaban sus bienes en propiedad, de lo que resultaban chocantes anomalías, que no siempre han sido bien comprendidas por los canonistas ${ }^{121}$.

${ }^{116}$ Publ. BARAUt, Els documents, dels anys 981-1010, op. cit., doc. 288, pp. 120-121.

${ }^{117}$ Publ, BARAUT, Els documents, dels anys 1010-1035, doc 315, pp. 28-31, y. Pere PuJOL I TuBau, L'urna d'argent de Sant Ermengol, bisbe d'Urgell, "Memớries de l'Institut d'Estudis Catalans. Secció historico-arqueologica", I (1927), pp. 1-29, reed. Obras completas, op. cit., pp. 407-428, 413, n. 15

${ }^{118} \mathrm{El}$ fragmento no tiene desperdicio: "Preterea ego Heriballus gratia Dei episcopus constituo in mee sedis Urgellensis canonica, cum domnis religiossimis episcopis, ut quadraginta canonici illic habeantur de illis qui in ecclesia maiores ese videntur cum suis clericis sibi subiectis qui statores sunt" (Publ. BARAUT, Les actes de consagracions d'esglésies, op cit., doc. 54, p 137). En 1134, el número aumentaría a cuarenta y cinco prebendas (BARAUT, Els documents, dels anys 1101-1150, op. cit. doc. 1436, p. 248). Las noticias sobre el cabildo previas al siglo XI estän recogidas en J. GARSABALL I RIVASES, La canonica abans de la canonica. El paper dêls canonges de la Seu d'Urgell fins a la institució del capítol el 1010, "Actes del Congrés Internacional Gerbert d'Orlhac", Vic, 1999, pp. 783-803.

${ }^{119}$ Publ. BARAUT, Els documents, dels segles IX $i$ X, op. cit., doc. 118, pp. 86-87.

${ }^{120}$ Para los monachi en las catedrales, CARRERO, La 'vita communis', op. cit., pp. 173-175.

${ }^{121} \mathrm{~V}$. DE LA FUENTE, Historia eclesiástica de España, II, Barcelona, 1855, p. 173. La cita a la incomprensión alude, claro está, a Jaime Villanueva y a su constante sospecha sobre la regularidad aquisgranesa en las sedes de la Marca. No en vano, sobre la coexistencia de un cabildo mayor propietario y otro menor sin propiedades, ahora para Roda de Isábena, llegó a suponer "los mạles que solîa y debía engendrar esta monstruosa canónica" (VILLANUEVA, Viage literario, op. cit., XV, p. 150). 
En su momento, destaqué el ascendiente que las reglas hispánicas y la vida del clero alrededor del prelado de la Hispania anterior al siglo X debieron tener en el desarrollo del canonicato preagustiniano peninsular, subrayando después la mélange de textos de distinto origen y procedencia que podían conformar unos estatutos capitulares, específicos y únicos para cada congregación capitular ${ }^{122}$. No sabemos si, como afirmó Villanueva, las mudanzas en el cabildo urgelitano a comienzos del siglo XI vinieron a raíz de la asistencia del obispo Sal-la al concilio de Barcelona, donde pudo conocer de primera mano la transformación a la que Aeci había sometido al clero de la sede barcelonesa ${ }^{123}$. Lo bien cierto es que la acción renovadora de Ermengol de Urgell en 1010 debe ser contextualizada en lo que ocurría en su propio medio geográfico y político - reformas de los cabildos de Barcelona (1009), Vic (1017), Girona (1019) y el sur de Francia en fechas paralelas- y de lo que ocurriría unas décadas después en el occidente peninsular con el concilio de Coyanza (1055). Y es que, muy por delante de la llamada reforma canonical gregoriana, la primera mitad del siglo XI fue una época de innovaciones y restauraciones dentro del tradicional movimiento pendular entre regularidad y secularización que caracterizó al clero de las catedrales europeas, hasta el generalizado abandono de la vida en común entre los siglos XIII y XIV.

Enlazando vida capitular y arquitectura, más que la refundación de una canónica ya existente, la gran complicación de la Seu d'Urgell en época del obispo Ermengol no es otra que el establecimiento de la iglesia de Sant Miquel y su por qué. Líneas arriba vimos cómo las primeras noticias sobre la misma datan de los años veinte del siglo XI, pero quizás la cuestión más conflictiva es que se haya planteado como una fundación destinada a albergar al nuevo cabildo refundado por el prelado en 1010. Basándonos exclusivamente en los documentos, Sant Miquel es efectivamente reconocida por Ermengol como fundación propia, pero en ningún momento nos dice que allí se instituyera la canónica catedralicia que, por el contrario, el mismo documento episcopal y todos los posteriores vinculan constantemente a Santa María: ad ipsam cannonicam sancte alme Marie Sedis vel ad ipsos cannonicos ibi Deo servientes $^{124}$. Echando más leña al fuego, veintisiete años después, en 1037, una donación tilda a San Miguel de monasterio - ad Sancto Michael cenobii, qui est prope Sancta Maria in ipsa Sede $e^{125}$-, en tanto que las referencias a una comunidad canonical no aparecen hasta 1095, aclarando que vivía bajo la regla de San Agustín, con alusiones dispersas entre dicho año y el de 1115. El resto de la documentación publicada de la segunda mitad del siglo XI y de todo el

\footnotetext{
${ }^{122}$ Eduardo CARRERO SANTAMARÍA, 'Ecce quam bonum et quam iocundum habitare fratres in unum'. Vidas reglar y secular en las catedrates hispanas llegado el siglo XII, en "Anuario de Estudios Medievales", 30/2 (2000), pp. 757-805, e ID., La 'vita communis'..., pp. 173-177.

${ }^{123}$ VILlanUeVA, Viage literario, op. cit., IX, pp. 169-170. 179.

${ }^{124}$ Publ. BARAUT, Els documents, dels anys 1010-1035, docs. 463 y 478, pp. 164-166 y 177-

${ }^{125}$ Publ. BARAut, Els documents, dels anys 1036-1050, op. cit., doc. 500bis, p. 41.
} 
XII insiste en hablarnos de Santa María de la Seu y su canónica, sin que aparezcan Sant Miquel y la suya. No es de extrañar, por tanto, que Jaime Villanueva se desesperara intentando diferenciar entre una comunidad 'aquisgranesa' cum proprio en la catedral de Santa María y otra de raigambre monástica en Sant Miquel, bajo la regla de San Agustín ${ }^{126}$. Que en 1095 fuera citada por primera vez la normativa agustiniana en relación a la catedral y, en particular, a Sant Miquel es un elemento de juicio interesante y a tener en cuenta y es que, ahora, en la segunda mitad del siglo XII, debió introducirse la reforma canonical agustiniana vía San Rufo de Aviñón ${ }^{127}$. Creo claro que la transformación de la canónica también afectó a la de Santa María. En 1116, Gerberga donaba a sus dos hijos al obispo Ot y a la catedral de Santa María, para que fueran recibidos como religiosos sub regula beati Augustini ${ }^{128}$. Por fin, una oblación de 1122, publicada por Jaime Villanueva, fue depositada in manu domni Odonis episcopi, ut sit clericus canonicus Santae Mariae sedis Urgellensis secundum regulam Sancti Augustini ${ }^{129}$.

Poniendo todas las cartas sobre la mesa, contamos con dos cuestiones básicas para intentar iluminar - poco- la duda que nos ocupa: la primera es que en 1010 se refunda la canónica catedralicia urgelitana, pero siempre en relación a la iglesia principal de Santa María, en cuyo costado sur se localizaron los edificios dedicados a la vida comunitaria del clero inmediatos al palacio episcopal. La segunda es la fundación de una iglesia de Sant Miquel en el lado norte de la catedral que era tildada de monasterio en 1037y que a finales de siglo reconocía regirse bajo la regla de San Agustín marcando, por lo tanto, las posibles fechas para la llegada a la Seu de la revisión canonical promovida desde Roma. Podría plantearse la duplicidad entre iglesia episcopal y parroquial e iglesia de una comunidad sub regula, interpretando en este sentido el documento de 1095 que nos hablaba de la regla de San Agustín en Sant Miquel y los statores y missa cantantes de Santa María ${ }^{130}$. Creo que, de manera similar a la congregación de presbíteros documentada bajo contrato en el cabildo de Girona, los cunctos statores a los que se refiere el diploma son los hebdomadarios o semaneros ocupados del culto en Santa María. Además, llegados a este punto de certeza documental, ¿qué hacemos con Sant Pere, la segunda iglesia más antigua de todo el conjunto? Nada más fundarse Sant Miquel, el testamento del obispo Ermengol hacía una donación para el aceite

${ }^{126}$ VIllanUEVA, Viage literario, op. cit., IX, pp. 169-179, y Gros, La Consueta antiga, p. 187 , n. 11 .

${ }^{127}$ Recordemos que, en la Marca, los canónigos de San Rufo se encargaron de introducir la reforma clerical que se promovió desde Roma desde la segunda mitad del siglo XI, mientras en el occidente de la Península fueron los monjes de Cluny los que se hicieron cargo de obispados y cabildos en ambos casos introduciendo la regla de San Agustín y los estatutos particulares a cada institución, que limitaban su laxa normativa (CARRERO, Ecce quam bonum, op. cit., pp. 785800).

${ }^{128}$ Publ. BARAUT, Els documents, dels anys 1101-1150, op. cit., doc . 1285, pp. 114-115; Puig i CADAfAlCh y PuJOL I TuBAU, Santa Maria de la Seu, op. cit., p. 19.

${ }^{129}$ Publ. VillanueVA, Viage literario, op. cit., IX, p. 173.

${ }^{130}$ Publ. BARAUT, Els documents, dels anys 1093-1100, op . cit., docs. 1135 y 1142, pp. 60 y 67; Puig i CADAfalch y Pujol I TUBAU, Santa Maria de la Seu, op. cit., p. 19. 
que iluminaba los altares de la catedral, que entendía como un conjunto unitario de tres iglesias, las de Santa María, San Miguel y San Pedro: ...oleum ad crisma conficiendum et oleum ad sanctos altarios illuminandos, qui infra domum sancte Marie sunt aud erunt, et sancti Michaelis Archangeli et sancti Petri apostoli ${ }^{131}$. Si habíamos considerado que Santa María y Sant Pere habían conformado la estructura canónica de un conjunto dúplice hasta el pontificado de Ermengol, podemos suponer que en tales funciones - las canonicalescontinuaría hasta el abandono de la vida común en el siglo XIII. Que a comienzos del siglo XI se instituyera un segundo establecimiento al norte de la catedral, el de Sant Miquel, y fuera considerado parte de ésta sólo es comprensible desde la óptica de los poblados atrios de la Alta Edad Media y su variable número de comunidades y oratorios al servicio del culto, $\mathrm{y}$ no desde la duplicidad reglar y secular del propio clero catedralicio ${ }^{132}$. Lo realmente singular, lo que ahora se me escapa de todas todas es cuáles fueron las razones de Sant Ermengol para crear una segunda canónica en la catedral, canónica a la que la lectura entre líneas de la documentación capitular prolonga la vida hasta la secularización del propio cabildo de Santa María de la Seu.

\section{CATEDRAL Y LiTURGia. LA SEU D’URGELl EN CONTEXTO}

La Consueta antigua de la catedral, citada en varias ocasiones a lo largo de las páginas previas, es una fuente datada entre 1133 y 1173 y tiene el privilegio de tratarse, en su tipo, de uno de los códices litúrgicos más antiguos de las sedes catalanas y, por ende, de la iglesia hispana. Dado que la construcción de la catedral tardorrománica se dilató a lo largo de todo el siglo XII, lo más lógico es pensar que las referencias topográficas que incluye se están refiriendo al conjunto levantado durante el pontificado de Ermengol y décadas afines. El ejemplar más completo de la consueta se conserva en el Museu Episcopal de Vic (Vic, Mus. Episc., Ms. 131), mientras un bifolio de la que fue una segunda copia está hoy en manos privadas, habiendo sido publicados ambos, íntegramente, por Miquel dels Sants Gros en 1978 y $2005^{133}$.

El contenido del Libro de costumbres es el calendario litúrgico del cabildo catedralicio desde el Adviento hasta el Pentecostés, con algunos anejos dedicados a festividades móviles concretas. A diferencia de otros documentos

\footnotetext{
131 "Et ad altari sancte Marie, die et nocte, et ad ipsam cannonicam". (publ. BARAUT, Els documents, dels anys 1010-1035, doc. 463, pp. 165-166). La triple advocación la vuelve a repetir referida a una estructura eclesiástica indivisa al final del documento.

${ }^{132}$ Véanse, por ejemplo, las noticias sobre el atrio de la catedral de Astorga (Eduardo CARRERO SANTAMARIA, La claustra y la canónica medieval de la catedral de Astorga, "La catedral de Astorga (Actas del Simposio)", Astorga, 2001, pp. 85-156).

${ }^{133}$ GROS, La Consueta antiga op. cit.; ID . Un fragment de l'antiga consueta op. cit. . y Francesc Xavier PARÉS I SALTOR, L'Ordinari d'Urgell de 1536, La Seu d'Urgell, 2002, pp. 6768 .
} 
semejantes, un rasgo definitorio del costumbrario urgelitano es su escaso detenimiento en el ceremonial ${ }^{134}$. Para liturgistas y musicólogos nuestro códice es de un indudable valor, al reseñar puntualmente todos los textos leídos y cantados durante los oficios, la liturgia de las horas, las fiestas particulares y las procesiones en una comunidad canonical marcada por su carácter reglar ${ }^{135}$. Por el contrario, sus rúbricas son esencialmente lacónicas en lo referente al rito y, por lo tanto, en las notas que su redactor pudiera habernos brindado sobre la topografía catedralicia urgelesa a partir de las celebraciones de su cabildo. Sólo en determinadas festividades algunas glosas sobre la aspersión del templo, el regado del coro, las procesiones bautismales o la del Domingo de Ramos con su sermón al pueblo, el modo de celebrar la comunión en la Cena Domini, la forma de llevar cruces, incensarios y candelabros procesionalmente tras el mandato o, en la Natividad, la celebración del Ordo Prophetarum y la Sibila en la novena lección de maitines - Inter pressuras cum prophetis et cum Iudicii signum cantando-, parecen llamar nuestra atención sobre el ceremonial del siglo XII y sus posibilidades de interpretación.

Recientemente parece existir un brioso interés en el Domingo de Ramos por parte de la historiografía al uso ${ }^{136}$. Y no es de extrañar, ya que se trataba de una de las ceremonias más multitudinarias entre las que jalonaban el año litúrgico. Los propios orígenes de la festividad en la liturgia hierosolimitana son los que marcaban un cambio del espacio de celebración que permitiera dotar a la misma de un ámbito adecuado y diferente del habitual. Al fin y al cabo, la Dominica palmarum es prototipo del factor memoria, del recuerdo y conmemoración de la vida y acciones de Cristo característicos de

\footnotetext{
${ }^{134}$ Sobre el tema de las Consuetas en territorio catalán, Antoni PLADEVALL y Josep Maria PONS GURT, Particularismes catalans en els costumaris dels segles XIII-XVIII, "II Congrés Litúrgic de Montserrat”, Montserrat, 1967, pp. 103-159. Los datos que contienen han sido utilizados puntualmente en algunos trabajos (v.gr. las de Girona y Vic o la del monasterio de Sant Cugat del Vallès, en ESPAÑOL, Massifs occidentaux.... Immaculada LORES I OTZET, La vida en el claustre: iconografia monàstica als capitells de Sant Cugat del Vallè $i$ el Costumari del monestir, "Butlleti MNAC", 6 (2002), pp. 35-46, Peter K. KLEIN, Topographie, fonctions et programmes iconographiques des cloîtres: La galerie attenante à l'église, en "Der mittelalterliche Kreuzgang. The medieval Cloister-Le cloître au Moyen Âge. Architektur. Funktion und Programm", ed. P. K. KLEIN, Regensburg, 2004, pp. 105-158, en particular, pp. 140-145, ID., Le clôttre de la cathédrale de Gérone: fonctions et programme iconographique en "Patrimonio artístico de Galicia y otros estudios: homenaje al Prof. Dr. Serafín Moralejo Ǎlvarez" coord. Angela FrANCO MATA, 3 vols., Santiago de Compostela, 2004, III, pp. 139-144 y Marc SUREDA JUBANY, Els precedents de la Catedral de Santa Maria de Girona, Girona, 2008). En cualquier caso, los únicos de estos textos investigados de forma monográfica desde una perspectiva histórico-artística son la consueta y la Pretiosa ilerdenses, por Francesc FITÉ I LLEVOT, Ritual $i$ cerimònia a la Seu Vella de Lleida: les devocions, aniversaris i fundacions, "Imágenes y promotores en el arte medieval. Miscelánea en homenaje a Joaquín Yarza Luaces", Bellaterra, 2001, pp. 373-390, e ID., Litúrgia i cultura a la Seu Vella de Lleida, "Seu Vella,'l'esplendor retrobada", Lleida, 2003, pp. 98-129.

${ }^{135}$ Léanse las palabras de Francesc Xavier ALTÉS en El processoner de la Seu d'Urgell, op. cit. , pp. 31-32. También se ha visto entre sus contenidos el posible eco de la obligada mutación al rito romano de la comunidad catedralicia urgelesa en el siglo IX, revisada ya en el XII por los usos reformistas de San Rufo de Aviñón (GROS, La Consueta antiga, op. cit., pp. 187 y 189).

${ }^{136}$ Por ejemplo, la recopilación de fuentes recogidas en la reciente monografía sobre la catedral de Trondheim, entre las que no se encuentran las hispanas: David CHADD (ed .), Appendix II. Palm Sunday at Nidaros. Anthology of Sources, en "The Medieval Cathedral of Trondheim. Achitectural and Ritual Constructions in their European Context”, eds. Margrete SYSTAD, Øystein EKROLl, Andreas HAUG y Nils Holger PETERSEN, Turnhout, 2007, pp. 319-354.
} 
toda la liturgia católica. Así, tomando como base el relato evangélico, la comunidad cristiana de Jerusalén estableció un recorrido litúrgico estacional desde el monte de los Olivos hasta la Anástasis, según refirió la peregrina Egeria en el siglo IV. De esta suerte, la ceremonia pasó a celebrarse en las iglesias del resto de la cristiandad, adaptándose y acomodándose a los escenarios particulares de cada lugar. La congregación partía desde el coro hacia otro lugar de las inmediaciones del templo - la emulación del monte de los Olivos-, donde se bendecían palmas, se explicaba el sermón y se regresaba a la iglesia, ahora entendida como auténtica Jerusalén. Entre el clero se solía establecer la equivalencia con Cristo y los Apóstoles e, incluso, incorporar elementos parateatrales como los palmesel o pasos esculpidos representando a Cristo bendiciendo a lomos del asno ${ }^{137}$. Es bien cierto que cada comunidad adaptó la ceremonia al medio arquitectónico y urbano en el que se desenvolvía. La consueta urgelitana sólo especifica el encabezamiento de la procesión por el clero aspergiendo y su itinerario ad locum constitutum donde se leía el Evangelio y se bendecían los ramos, se dictaba el sermón y desde el que se volvía finalmente a la iglesia ${ }^{138}$. Tendremos que esperar a la consueta de 1418 y al procesionario de 1527 para encontrar recogida la mención concreta a la procesión claustral dominical del día, en la que se bendecían los ramos, y la salida de la comitiva capitular hacia el Prat de Sant Ermengol, es decir, la huerta del Segre donde se encontraba la ermita dedicada al santo obispo y localizada muy cerca de la cabecera de la catedral. Desde allí se regresaba a la ciudad a través de la puerta de la Cerdanya, recordando la entrada de Jesús en Jerusalén, cantando las antífonas y pronunciándose el sermón correspondiente. El recorrido por la ciudad hacía diversas estaciones en torres - la del deán, la de Sant Joan y la de Sant Sadurní- y en el enlosado de San Marcos, donde los niños de coro cantaban distintas estrofas del himno Gloria, laus et honor, hasta que el deán golpeaba las puertas de la catedral, tornando finalmente a la misma ${ }^{139}$. El uso de las murallas de la ciudad y las torres de algunas casas fuertes e iglesias tiende el vínculo a una imaginada topografía sacra de Jerusalén, reproducida en la Seu. En efecto, se trata de una ceremonia común a todas las iglesias europeas, en las que sólo cambia el escenario urbano, adaptado a las peculiaridades de cada ciudad. Veamos algunos ejemplos. Sin salir del ámbito catalán, la consueta vicense del siglo XIII es más elocuente. Narra cómo la procesión daba inicio con el cabildo en el coro y el obispo en la sacristía, revistiéndose de todos los mejores ornamentos junto a sus clérigos y niños acompañantes. Dirigéndose hacia el

\footnotetext{
${ }^{137}$ El relato sobre sus orígenes, primeras noticias en las iglesias de Occidente y evolución del ceremonial en Mario RIGHETTI, Historia de la liturgia, 2 vols., Madrid, 1955, I pp. 777 785. Trata sobre el particular Gloria FERNÁNDEZ SOMOZA, Pintura románica y configuración espacial en el Monasterio de San Juan de la Peña. La vieja sala capitular en la Capilla de San Victorián. "Hortus Artium Medievalium", 15/2 (2009), pp. 393-401, con las referencias bibliográficas oportunas. Las analogías iglesia-Jerusalén, obispo-Cristo, clero-Apostolado para la procesión de Ramos es un lugar común evidente.

${ }^{138} \mathrm{Gros}$, La consueta antiga, op. cit., p. 223.

${ }^{139}$ ALtés I AGUiLó, El processoner de la Seu d'Urgell, op. cit., p. 41.
} 
altar mayor, comenzaba el Asperges me y junto a ministros, cruces, candelabros, salían del coro. Mientras, el chantre encabezaba la procesión al claustro, cantando determinadas antífonas. De allí regresaban hasta el altar de la cripta catedralicia. Mientras, el clero que había permanecido en el coro, salía hacia el altar de San Nicolás - muy posiblemente localizado en el antecoro- y, luego, al lugar donde se cantaba el Salve rex fabricator mundi. Aquí se realizaba una primera genuflexión hacia oriente y una segunda -momento en que el hebdomadario incensaba las cruces y los altares-, hacia las cruces procesionales, los ornamenta de la procesión y las vexilla, que, mientras tanto, se habían acercado hasta la puerta occidental de la catedral, encabezados por el obispo. Tras salir, permanecían entre la iglesia mayor de Sant Pere y la vecina de Santa María de la Rodona, a poniente de la catedral, donde los versículos se cantaban en dos coros divididos entre las puertas de ambos templos. Después se daba entrada en la Rodona, sobre cuyo altar el obispo bendecía los ramos. Saliendo, la procesión continuaba hasta la vega del río Mèder, en la que se sucedían las consecuentes antífonas, la lectura del Evangelio, silencio y el sermón ad populum et clerum. En el retorno a la catedral de Sant Pere, la Jerusalén evangélica, los cantos alusivos continuaban, entrando en su interior y dividiéndose de nuevo con el clero al coro y el obispo a la sacristía, de donde volvería para celebrar la misa solemne ${ }^{140}$. En Girona, la ceremonia también tenía un complejo carácter procesional que podía optar entre dos posibilidades, o la división del ceremonial entre obispo, ministros y otro clero entre la catedral y San Félix, reuniéndose después, o su concentración en el claustro, según recoge la consueta de $1360^{141}$. La duplicidad de espacios de celebración durante el Domingo de Ramos también la encontramos en Tarragona entre los siglos XV y XVI, cuando el cabildo bajaba en procesión desde la catedral hasta la iglesia de Sant Fructuós. Allí se leía el Evangelio y se dictaba el sermón, pero los ramos eran bendecidos en un lugar cercano, parece que detrás de la citada iglesia. La vuelta a la catedral era más compleja ya que - al igual que ocurría con las torres de la Seu-, las murallas de la ciudad eran incluidas como elemento escenográfico, convirtiéndose circunstancialmente en las defensas de Jerusalén, con las puertas cerradas y desde cuya torre d'en Bort de Vignes cantaban los escolanes. Tras abrir las puertas, la procesión se dirigía a la explanada frente a la puerta occidental de la catedral - también cerrada-y, finalmente, al interior del templo ${ }^{142}$.

\footnotetext{
${ }^{140}$ Miquel dels Sants Gros I PUJOL, El 'Liber consuetudinum Vicensis Ecclesie' del canonge Andreu Salmúnia-Vic, Museu Episcopal, MS. 134 (LXXXIV)- "Miscel-lània Litúrgica Catalana", D. J. R. V.., Ceremonias que a principios del siglo XIII se observaban en la Sta. Iglesia de Vich el domingo de Ramos, y dias siguientes de la Semana Santa hasta el viernes inclusive, Vic, 1832.

${ }^{141}$ Bastante ofuscada en minimizar mis aciertos y subrayar mis errores en materia catedralicia, la tesis de M. Sureda aporta interesantes novedades documentales sobre Girona, aunque, en conjunto, esté cargada de apriorismos -entre otros, arqueológicos-, dando una vuelta de tuerca más a la equívoca reconstrucción planimétrica de la seo románica con la que se juega desde hace unas décadas, aderezada con cuestionables lecturas simbólicas de sus espacios (Marc SUREDA JUBANY, Els precedents de la Catedral..., op. cit.).

${ }^{142}$ Andrés TOMÁs ÁvILA, El culto y la liturgia en la Catedral de Tarragona (1300-1700), Tarragona, 1963, pp. 61-63.
} 
Volviendo al siglo XII y a la Seu d'Urgell, la descripción de la desnudez de las solemnidades de la Pascua es algo más explícita en detalles. En Viernes Santo se realizaba el sepulcro y la subsiguiente adoración de la Cruz, prolongando un ritual perfectamente establecido desde siglos previos, como demuestra su importancia para la iglesia hispánica, en la que se unían la propia adoración de la cruz y la reconciliación de los penitentes ${ }^{143}$. Siguiendo la consueta urgelitana, la ceremonia comenzaba suprimiendo la iluminación del templo, se apagaban las velas, evitando el uso de luminarias e incienso; los canónigos y el oficiante se descalzaban y éste último, sin casulla, vestía una capa negra y roja a juego con los paños que cubrían las paredes de la capilla mayor cuyo altar, a su vez, sólo estaba cubierto con dos manteles que pendían por los lados y que simbolizaban las palabras del Evangelio de San Juan Partiti sunt vestimenta mea (Jn, 19, 24), tras cuya enunciación se retiraban de la mesa. La adoración de la Cruz comenzaba mediante su alzamiento durante los juegos de cantos entre clero y niños de coro, para depositarla después en el lugar pertinente y preparado - honorifice preparatum-, a modo de sepulcro. Quizás se tratara de la misma cruz que se estaba realizando para la catedral en 1095 y en cuya finalización el tesorero Guillem empleó todo el oro y la plata que poseía ${ }^{144}$. Después de depositada la cruz en el lugar pertinente - en el Ordo romano era la superficie previa al altar mayor-, por riguroso orden, el obispo y el clero oficiante, el cabildo y finalmente los laicos - viris et mulieribus - , podían acercarse a besarla ${ }^{145}$. En el Liber Ordinum hispánico era una Crux aurea cum reliquiis clausa que era llevada procesionalmente desde la principalis ecclesiae hasta la de Santa Cruz,

\footnotetext{
${ }^{143}$ RigheTti, Historia de la liturgia, op. cit., I, pp. 805-808. Para la liturgia hispánica, Ramon ORDEIG I MATA, L'ordre hispanic del Divendres Sant sengons la tradicio A, "Revista Catalana de Teologia”, 2 (1977), pp. 453-484, y Miquel dels Sants GROS I PUJOL, Fiestas y liturgia en el 'Liber Ordinum' hispanico, "Fêtes et liturgie. Actes du colloque tenu à la Casa de Velazquez, 12/14-XII-1985", coords. Alfonso ESTEBAN y Jean-Pierre ETIENVRE, Madrid, 1998, pp. 11-20 (15-17).

144 "Et quantum aurum et argentum abeo reliquo ad crucem Sancte Marie et fiat in potestate Ermengaudo Bernardi propter hoc ut ad perfeccionem iam dicta crux", publ. BARAUT, Els documents, dels anys 1093-1100, op. cit., docs. 1135 y 1142, pp. 59-61 y'66-68. Ya en 1010 el obispo Sal'la había donado cincuenta libras de oro para una cruz destinada al altar de Santa María (pub1. PUJOL I TUBAU, Els testaments de tres bisbes, op. cit., doc. II, p. 111; BARAUT, Els documents, dels anys 981-1010, op. cit., doc. 314, p. 145).

${ }^{145} \mathrm{La}$ ceremonia, más detallada, es descrita en los Ordines Romani en la Alta y Baja Edad Media, cf. Michel ANDRIEU, Les Ordines Romani du Haut Moyen Age, vol. V, Les Textes (Ordo L), Lovaina, 1961, pp. 245-260, ID., Le Pontifical Romain au Moyen Áge, 3 vols. Ciudad del Vaticano, 1938-1940, I, pp. 234-237, II, pp. 464-469 y III, pp. 582-589; Marc DYKMANS, Le Cérémonial papal de la fin du Moyen Age a la Renaissance, 4. vols., Bruselas-Roma, 1977-1985, II, pp. 386-393, III, 213-222 y IV, 146-156 También recogida por el cardenal Bernardo en su Ordo lateranense del siglo XII, Bernhardi Cardinalis et Lateranensis Ecclesiae Prioris. Ordo Officiorum Ecclesiae Lateranensis, ed. Ludwig FISCHER, Munich y Freising, 1916, pp. 55-59. Puede seguirse su importancia a través de distintos textos europeos en Lilli GJERLøW, Adoratio Crucis. The Regularis Concordia and the Decreta lanfranci: manuscript studies in the early medieval Church of Norway, Oslo-Londres-Boston, 1961, y las adiciones al catálogo -incluyendo una bonita rúbrica recogida en el Pontifical de Braga del siglo XII- de Joaquim O. BRAGANÇA, A Adoração da Cruz na espiritualidade de Occidente " "Didaskalia", 5 (1975) , pp. 255-281, reed. en ID., Liturgia e espiritualidade na Idade Média, Lisboa, 2008, pp. 209-229.
} 
sin especificar separación entre sexos a la hora del ósculo ${ }^{146}$. También en la descripción de la adoración de la cruz en el Triduum Sacrum romano del siglo IX (Ordo XXIII, s. IX) prescribe el uso de una cruz pretiosae de oro y gemas - como debió ser la de la Seu-y, a diferencia de nuestra consueta, legisla un riguroso orden en el ósculo en el que se segregaba a los fieles masculinos de los femeninos, a quienes debía llevarse la cruz ex profeso a su lugar de asistencia a los oficios, dado que no podían acceder hasta el altar mayor de la iglesia lateranense de la Santa Cruz de Jerusalén, donde el crucifijo se depositaba ${ }^{147}$. Después del ósculo de clero y pueblo, la cruz era devuelta a su lugar de origen y los celebrantes podían vestir los ornamentos litúrgicos apropiados, iluminar el altar y proceder a la Eucaristía ${ }^{148}$. No nos consta el lugar concreto de depósito de la cruz. Es posible que el altar para su adoración se localizara en el antecoro de la catedral, en paralelo a los grandes Calvarios que remataban antecoros y trascoros, a veces sustituyendo al que se situaba sobre una viga cruzada en el arco triunfal ${ }^{149}$. Señalemos, en fin, que con seguridad en todo este proceso algún papel tendría el altar de la Santa Cruz documentado en 1178 in ecclesia Sedis y que, hasta la reordenación de altares de la catedral tardorrománica en el siglo XVI, ocupó el ábside norte inmediato a su capilla mayor ${ }^{150}$.

Junto a todas estas interesantes noticias, es en el orden de las Letanías cuando la Consueta de la Seu aporta mayores noticias topográficas, al reglamentar una procesión por la catedral y su entorno en el miércoles de Letanías. Es de rigor notificar aquí que, si las letanías fueron -como se describirá ahora- una de las festividades más solemnes de la Iglesia occidental, en nuestro caso y en los textos cantados y en sus plegarias - también descritos en el Misal del obispo Galceran de Vilanova (1388-1415) y en la Consueta de 1418- es una manifestación litúrgica propia de la Seu d'Urgell, siguiendo un esquema que no se repite en otras iglesias de Cataluña, según puntualiza Francesc X. Parés ${ }^{151}$. Los orígenes de la fiesta se sitúan en las Litaniae maiores romanas, conocidas desde Gregorio Magno (540-604), asentadas en la procesión que el 25 de abril recorría Roma desde San Lorenzo in Lucina hasta San Pedro del Vaticano, con estaciones dentro y fuera de los

\footnotetext{
${ }^{146}$ Marius FÉROTIN, Liber Ordinum en usage dans l'église wisigothique et mozárabe d'Espagne du cinquième au onzième siècle, [1904], reed. de Anthony WARD y Cuthbert JOHNSON, Roma, 1996, cols. 193-204.

${ }^{147}$ Michel ANDrIEU, Les Ordines Romani du Haut Moyen Âge, vol. III, Les Textes (Ordines XIV-XXXIV), Lovaina, 1974, pp. 270-271, y. Marco RomANo L'Oratorio della S. Croce al Laterano. Preliminari di un 'indagine archeologica-topografica, "Żeitschrift für Kunstgeschichte", 59-3 (1996), pp. 337-359.

${ }^{148} \mathrm{GrOS}$, La Consueta antiga, pp. 226-227. El rito es idéntico en el Ordinario de la catedral de 1536 (PARÉS I SALTOR, L'Ordinari d'Urgell, op. cit., pp. 118-120).

${ }^{149}$ Véase aquí M. BEER, Triumphkreuze des Mittelalters. Ein Beitrag zu Typus und Genese im 12. und 13. Jahrhundert. Mit einem Katalog der erhaltenen Denkmäler, Regensburg, 2005.

${ }^{150}$ Publ. BARAUT, Els documents, dels anys 1151-1190, op. cit., doc. 1742, p. 260. Sobre los altares, PUJOL I TUBAU, L'església de la Pieta, op. cit., p. 386, n. 5 , e ID., L'urna d'argent, op. cit., p. 416 , n. 22.

${ }^{151}$ PARÉS I SALTOR, L'Ordinari d'Urgell, op. cit., pp. 140-141.
} 
muros de la ciudad ${ }^{152}$. Por el contario, en el siglo VIII, el Ordo Romanus XXI reglamentaba esta celebración pero obviando toda alusión a un recorrido complejo y desarrollado, indicando únicamente cómo la comitiva litúrgica circulaba por el templo y su atrio encabezada por los pobres del hospital llevando la cruz de madera pintada, seguidos de las siete cruces portadas por los staurophoros, los ceroferarios, el obispo acompañado por presbítero y subdiácono, el oficiante y los diáconos con dos cruces, y por el clero de la iglesia cerrando el cortejo ${ }^{153}$. Entre los siglos VIII y IX a las letanías mayores se les unieron las menores, instituidas por el papa León III (795-816), que constaban de tres procesiones del triduo previo a la Ascensión: una entre Santa María la Mayor y su capilla del Pesebre y Letrán, otra a Santa Sabina y a San Pablo y la tercera a Santa Cruz de Jerusalén y San Lorenzo Extramuros ${ }^{154}$. Ya en el siglo XII, el prior lateranense Bernardo nos describe ambas procesiones como algo mucho más complejo de lo que refería el Ordo XXI. Las letanías mayores partían desde Letrán, camino del Vaticano, pasando por Santa María la Nueva y San Marcos. Una vez en San Pedro, había salidas a Castel Sant'Angelo, Santa María, y vuelta a la basílica apostólica, su confessio y la capilla de San Esteban, para regresar después a Letrán. Respecto a las letanías menores, en ellas participaban los capitulares lateranenses, Santa María la Mayor y San Pedro del Vaticano junto al clero de otras iglesias en un recorrido que, saliendo de la basílica del Salvador, realizaba sus estaciones en Santa María la Mayor, San Pedro ad Vincula, San Clemente, San Pablo Extramuros, San Eusebio o San Lorenzo Extramuros ${ }^{155}$.

En la Seu d'Urgell, la consueta de 1418 relata las procesiones del lunes y el martes de Letanías hasta las iglesias extramuros de Santa María Magdalena y Sant Pere de Somont, respectivamente ${ }^{156}$. Pero es la Consueta del XII y su procesión del miércoles las que más nos interesan ya que, si el esquema de cantos y plegarias era singular, también lo fue la expresión material de la festividad, adaptada a una topografía urbana concreta y condicionada por su propia historia institucional y arquitectónica. Tras la aspersión de los altares y el canto de antífonas, salmos y oraciones, la comunidad descalza se dirigía desde la catedral de Santa María hacia las

\footnotetext{
${ }^{152}$ RighetTI, Historia de la liturgia, op. cit., I, pp. 847-853.

${ }^{153}$ ANDRIEU, Les Ordines Romani, op. cit., vol. III, pp. 239-249.

${ }^{154}$ Le Liber Pontificalis, ed. L. DuCHESne, 2 vols., París, 1955, reed. París, 1981, II, p. 12.

${ }^{155}$ Bernhardi Cardinalis et Lateranensis Ecclesiae Prioris, op . cit., pp. 94-101. Al respecto, Sible DE BLAAUW, Cultus et decor. Liturgia e architettura nella Roma Tardoantica e Medievale 2 vols., Roma, 1994, I, pp. 313-316 y II, pp. 723-724, y, del mismo autor, Following the Crosses. The Processionat Cross and the Typology of Processions in Medieval Rome, en "Christian Feast and Festival. The Dynamics of Western Liturgy and Culture", eds. Paulus G. J. POST, G. ROUWHORST, Louis VAN TONGEREN y A. SCHEER, Lovaina-París-Sterling (Virginia), 2001 pp. 319-343, y Contrasts in Processional Liturgy: A Typalogy of Outdoor Processions in Twelfth-Century Rome. "Art, cérémonial et liturgie au Moyen Age", eds. Nicolas BOCK, Peter KURMANN, Serena ROMANO y Jean-Michel SPIESER, Roma, 2002, pp. 357-396. Para su evolución posterior, véase el trabajo de André VAUCHEZ, Liturgie et culture folklorique: les rogations dans la Légende Dorée de Jacques de Voragine, "Fêtes et liturgie. Actes du colloque tenu à la Casa de Velázquez", coords. Alfonso EsteBAN y Jean-Pierre ETIENVRE, Madrid, 1988, pp. 21-34.

${ }^{156}$ AltÉS I AGUILÓ, El processoner de la Seu d'Urgell, op. cit., pp. 42-43.
} 
puertas de la iglesia de San Pedro, donde se producía el habitual diálogo entre coros, para entrar después en la iglesia donde se repetía la ceremonia. En el interior del templo se aspergían altares y se rezaban las oraciones de los Santos Pedro, Pablo y Andrés, tras las cuales se reanudaba la procesión, esta vez hacia la iglesia del Santo Sepulcro. Una vez aspergidos sus altares y rezadas las preces reglamentarias, se dirigían entonces a las puertas de la iglesia de San Miguel, encomendándose los cantos a los Arcángeles, para regresar finalmente a la catedral de Santa María ${ }^{157}$. Evidentemente, el factor procesional superaría con creces las festividades reseñadas. Hasta la fecha, carecemos de una edición de la documentación bajomedieval y, sobre todo, del cruce de información entre ésta, y las noticias sobre tiempos litúrgicos y el santoral urgelés contenidas en el Misal del obispo Galceran de Vilanova (c. 1396), el del siglo XIV atribuido a la iglesia de Santa Eulalia, la consueta del siglo XV y el breviario impreso de $1487^{158}$. Un trabajo de estas características indudablemente aclararía interrogantes para la catedral tardorrománica y su evolución funcional hasta fechas modernas.

En efecto, buena parte de la procesión de letanías previa a la festividad de la Ascensión se mantuvo en el siglo XVI, aunque es interesante reseñar cómo los cambios en la topografía del propio entorno catedralicio hicieron variar su recorrido. La entrega de la iglesia de Sant Miquel a los dominicos en 1364 la había hecho desvincularse institucionalmente de la congregación catedralicia, favoreciendo la apertura de la calle de Oms que corre paralela a la catedral y que segmentaría el conjunto de atrios característicos de la reforma del siglo XI. Aún así, se mantuvo la antigua estación procesional, ahora en el convento de Santo Domingo, mientras la advocación de Sant Miquel era trasladada sustituyendo a la de Sant Pere, en su iglesia al sur de la de la catedral. Pero el cambio más elemental fue la inclusión de Santa Eulalia en el recorrido, en sustitución del Santo Sepulcro que, como vimos líneas arriba, se perdió en un momento indeterminado entre los siglos XIV y $\mathrm{XV}^{159}$.

\footnotetext{
${ }^{157}$ Gros, La Consueta antiga, p. 232. Simplemente citar que en Vic las letanías o rogaciones quedaban circunscritas al estricto entorno catedralicio, con una solemne procesión por todos sus altares y la vecina iglesia de Santa María, con cruz procesional y velas, que finalizaba con una misa en el altar de San Pedro de Confessione, en la cripta (GROS, El Liber Consuetudinum Vicensis Ecclesie, op . cit., p. 231). Mientras las consuetas tarraconenses entre los siglos XIV y XVI describen al fadrí que encabezaba la procesión de letanías como draconario, portando la serpiente alusiva a la victoria del bien, y las misas de cada uno de los tres días de las letanías menores, que se repartían entre San Fructuoso, Nuestra Señora del Milagro y Sanța Tecla la Vieja, con su procesión respectiva desde la catedral (TOMÁS AVILA, El culto y la liturgia, op. cit., pp. 107-110).

${ }^{158} \mathrm{Cf}$. PUJOL I TuBAU, Els dos missals mixtos, op. cit., Alexandre OLIVAR, El Missal de Galceran de Vilanova, bisbe d'Urgell, "Urgellia", 7 (1984-1985), pp. 489-498, PARÉS I SALTOR, L'Ordinari d'Urgell, op. cit., pp. 61-64, y ALTÉS I ÁGUILÓ, El processoner de la Seu d'Urgell, op. cit., pp. 11-47.

${ }^{159}$ PARÉS I SALTOR, L'Ordinari d'Urgell, op. cit., pp. 140-141, y AltÉS I AgUILÓ, El processoner de la Seu d'Urgell, op. cit., pp. 42-43.
} 


\subsection{Topografía urbana, santos lugares y liturgia estacional}

Para terminar, una última reflexión. Una ojeada al grupo de advocaciones que conformaron el conjunto de Urgell II pone de manifiesto su dependencia y no sé si su vinculación a los lugares más importantes en cultos, devociones y sobre todo peregrinaciones de la plena Edad Media europea: junto a la catedral de Santa María, la iglesia de San Pedro, San Pablo y San Andrés, la de San Miguel y los Arcángeles, la de Santa Eulalia de Barcelona y la del Santo Sepulcro. Josep Gudiol nos dejó un estudio modélico sobre los documentos relativos a la peregrinación catalana a distintos sacros lugares, entre los que destacan precisamente aquéllos de los que dependen las dedicaciones de la Seu: Jerusalén y su Santo Sepulcro, Roma - y en particular a las basílicas de San Pedro y San Pablo-, Santiago de Compostela, San Miguel en Monte Gargano, etc ${ }^{160}$. De hecho, cuando se funda el Santo Sepulcro urgelitano a comienzos del siglo XI Jerusalén aún estaba en manos musulmanas: ¿un Sepulcro que remediara, como en tantas otras ocasiones, las dificultades del peregrinaje? Sería extraordinario encontrar una permuta de peregrinación a cambio de visitar alguna de las iglesias urgelitanas, como sí se documenta en las bulas papales para la recuperación cristiana de Tarragona - recordemos que el carácter de cruzada también afectaba a la reconquista peninsular - o en el hermoso diploma de consagración de la iglesia de Tolba en 1080, cuya visita y limosnas conmutaban la peregrinación a Tierra Santa, San Pedro de Roma, Santiago de Galicia, Santa Maria de Puy uel in aliam peregrinationem $^{161}$. A nadie se le escapará que entre la iglesia de San Pedro Apóstol, el santuario canonical de San Miguel y los Arcángeles, el Santo Sepulcro y la iglesita de Santa Eulalia nos falta una de las dedicaciones con un mayor potencial, la de Santiago, mientras sí contamos con el testimonio de numerosos peregrinos urgelitanos a Compostela, incluido el propio obispo Ermengol. Al mismo tiempo, como tuvimos ocasión de ver, uno de los altares que hubo en la catedral románica y que se perpetuó en la tardorrománica fue precisamente el del Apóstol y creo que no debemos perder de vista que el meteórico culto a Ermengol, inmediato a su muerte, terminó ligado al de Santiago no sólo en la topografía de la catedral - con sus altares vecinos-,

${ }^{160}$ GudIOL, De peregrins i peregrinatges, op. cit., 95-110. También, Josep Maria MARTí BONET, "Peregrinatio pro Christo' en el Diplomatario de San Oleguer, "Memoria Ecclesiae", XVIII (2001), Peregrinación y santuarios en los archivos de la Iglesia, pp. 101-123, y BACH, Pelegrins als grans santuaris medievals, op. cit. Aunque sea un asignatura pendiente de la historiografía barcelonesa, el culto medieval a Santa Eulalia debió acoger a peregrinos que ocupasen el hospital catedralicio más allá de los que hicieran parada de sus viajes a otros santos lugares. Así, el 21 de enero de 1038, unas casas episcopales eran destinadas a "hospitium peregrinis et pauperibus adventantibus" (Publ. Diplomatari de l'Arxiu Capitular de la Catedral de Barcelona, op. cit., doc. 584, pp. 996-997).

${ }^{161}$ GUDIOL, De peregrins $i$ peregrinatges, op. cit., pp. 97-98. Desde una perspectiva generalista y de especial relevancia para lo que aqui nos gustaría sugerir, Robert OUSTERHOUT, "Loca Sancta' and the Architectural Response to Pilgrimage, "The Blessings of Pilgrimage", ed. R. OUSTERHOUT, Urbana-Chicago, 1980, pp. 108-124. 
sino incluso en la iconografía del santo prelado, salpicada por el legendario hagiográfico jacobeo ${ }^{162}$.

Reflexionando de nuevo sobre el conjunto de advocaciones y su relación con la peregrinación, la Seu d'Urgell a comienzos del siglo XI tenía una singular relación topográfica con un mapamundi simbólico de las más importantes devociones. Si retomamos el asunto de los atrios, dextros y paisaje urbano, tratemos de contemplar una iglesia mayor de la Virgen que, en un espacio acotado y delimitado, quizás dotado de un muro o cerca, estuvo envuelta entre otras cuatro iglesias de advocaciones profundamente reveladoras para el imaginario religioso de la época y marcadas por recoger los más importantes espacios sagrados del momento. En estas mismas fechas, un personaje del medio eclesiástico de Ermengol, el obispo Oliba de Vic, estuvo detrás de la creación de dos de los edificios más evocadores y singulares del siglo XI peninsular: las rotondas marianas elevadas a occidente de las iglesias de de Sant Miquel de Cuixà y de Sant Pere de Vic, ambas marcadas por su carácter recordatorio y conmemorativo. Del mismo modo, en unos años, capillas del Sepulcro ocuparían los pisos altos en los macizos occidentales de las catedrales de Barcelona, Girona y Vic. ¿Resulta muy difícil plantear una topografía urbana de sacros lugares, concentrada en una catedral y su entorno? Se me dirá que ni la documentación de la época ni la Consueta litúrgica aluden en momento alguno a una voluntad de emulación de capitales del peregrinaje; aún así, fruto o no de la casualidad, el paisaje arquitectónico que rodeó a la catedral de Santa Maria de la Seu d'Urgell fue el de un conjunto de iglesias dedicadas a Santos Lugares, enlazadas en una compleja liturgia estacional hasta la Edad Moderna.

Fecha de recepción del artículo: marzo de 2009.

Fecha de aceptación y versión final: julio de 2009.

\footnotetext{
${ }^{162}$ Así se ha identificado en los restos de pintura mural que procedían de la correspondiente capilla en la cabecera de la catedral (Anna ORRIOLS I ALSINA, Un cicle de Sant Jaume $i$ Sant Ermengol a la catedral de la Seu d'Urgell, "El camí de Sant Jaume i Catalunya. Actes del Congres Internacional celebrat a Barcelona, Cervera i Lleida, els diez 1,17 i 18 d'octubre de 2003", Abadia de Montserrat, 2007, pp. 409-417). La dedicación apostólica en la Seu d'Urgell debe añadirse a las recogidas por Gerardo BOTO V ARELA, Cartografía de la advocación jacobea en Cataluña (siglos X-XIV), Ibid., pp. 277-296.
} 


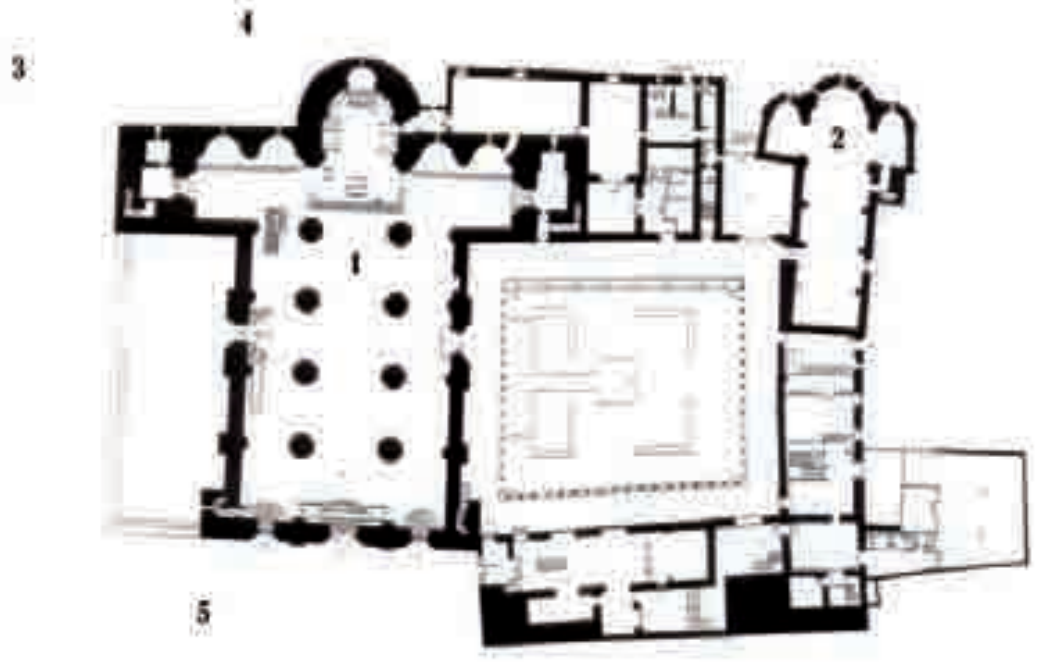

Fig. 1. Catedral de la Seu d'Urgell. Topografía del conjunto de comienzos del siglo XI sobre la planta actual. 1. Santa Maria; 2. Sant Pere; 3. Sant Miguel; 4. Santa Eulàlia; 5. Localización hipotética de la iglesia del Sant Sepulcre. 


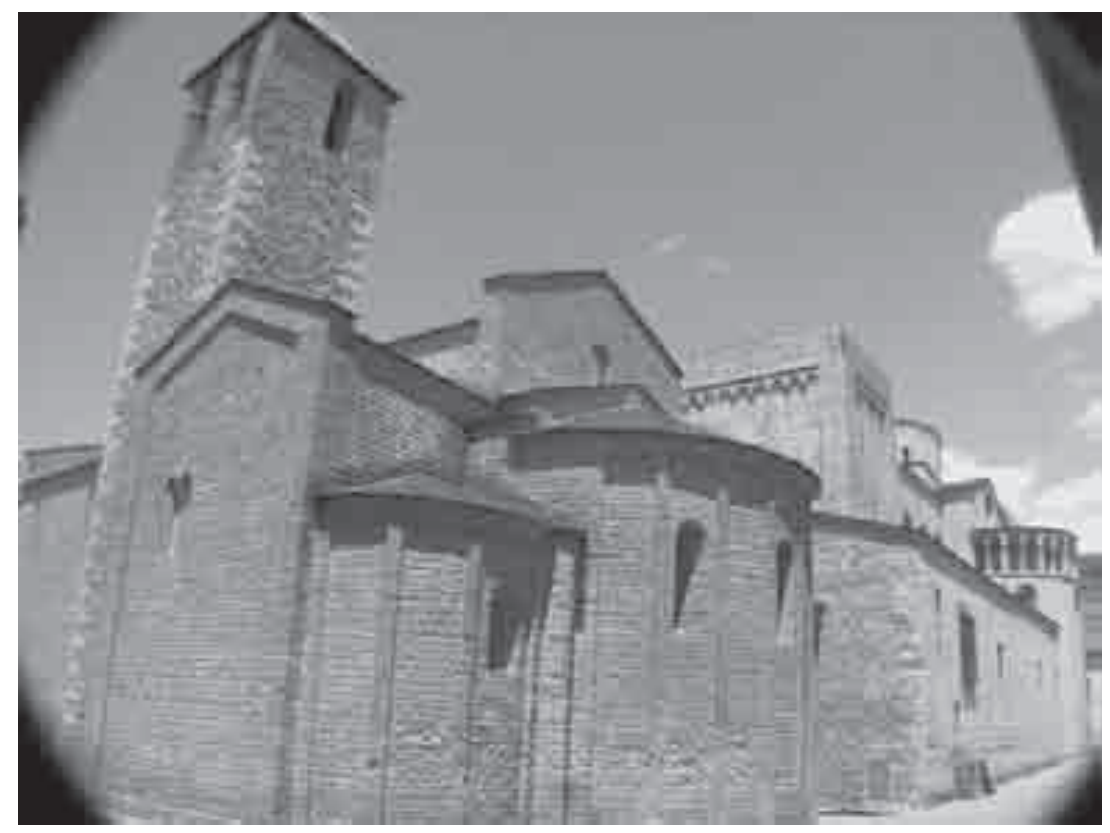

Fig. 2. Catedral de la Seu d'Urgell. Exterior sur de Sant Pere, visto hacia Santa Maria. 


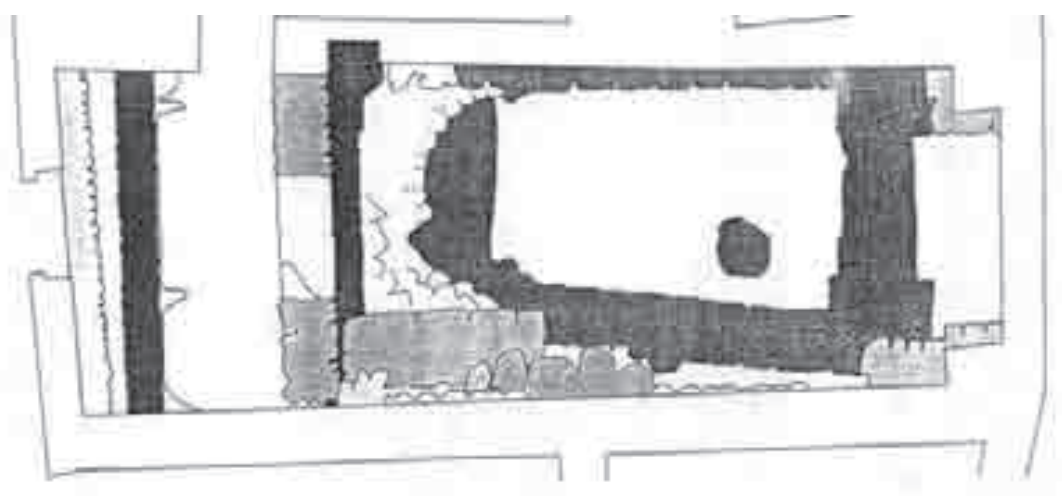

Fig. 3. La Seu d’Urgell. Planta de la excavación de la iglesia de Santa Eulàlia por Maria Àngels Ruf y Albert Villaró. 


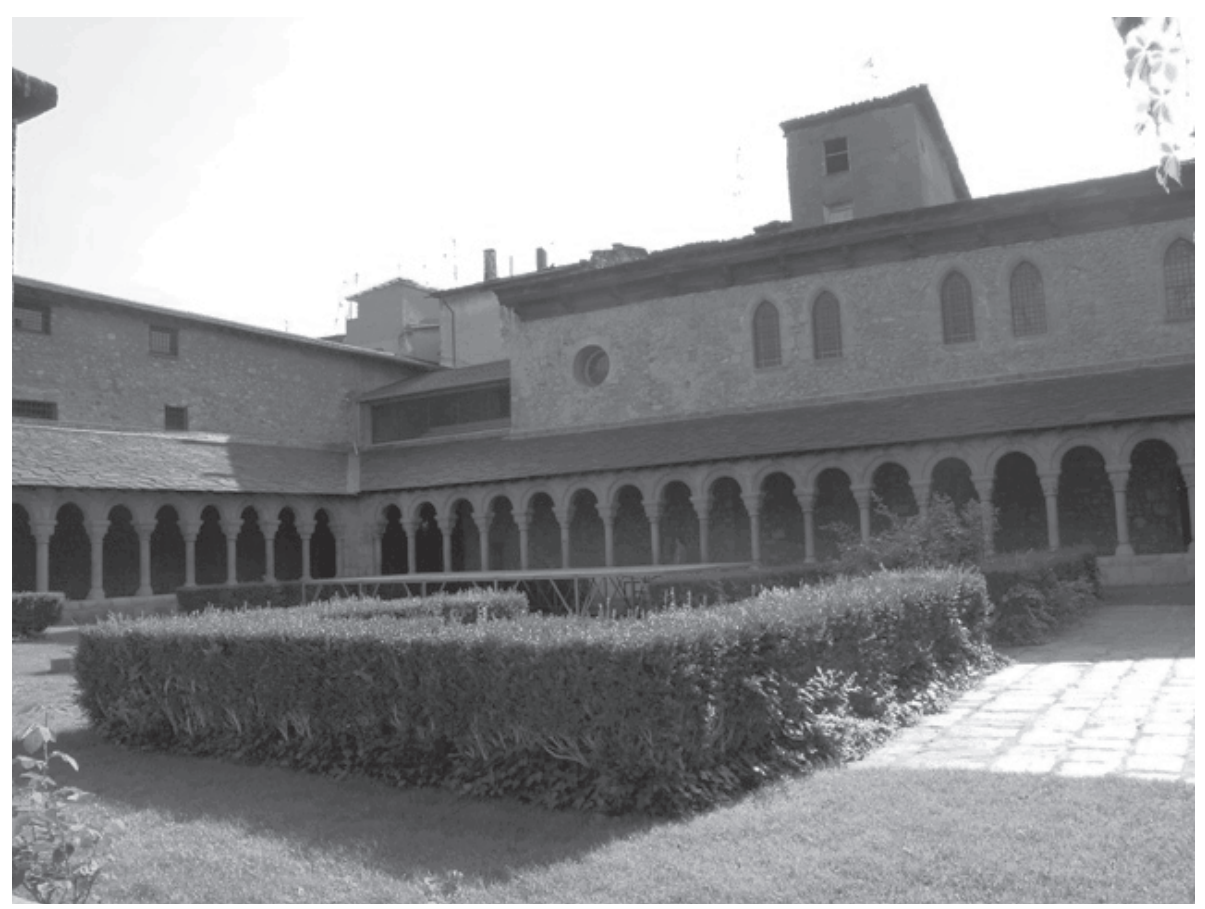

Fig. 4. Catedral de la Seu d’Urgell. Dependencias de la canónica (hoy Museu Diocesà) 


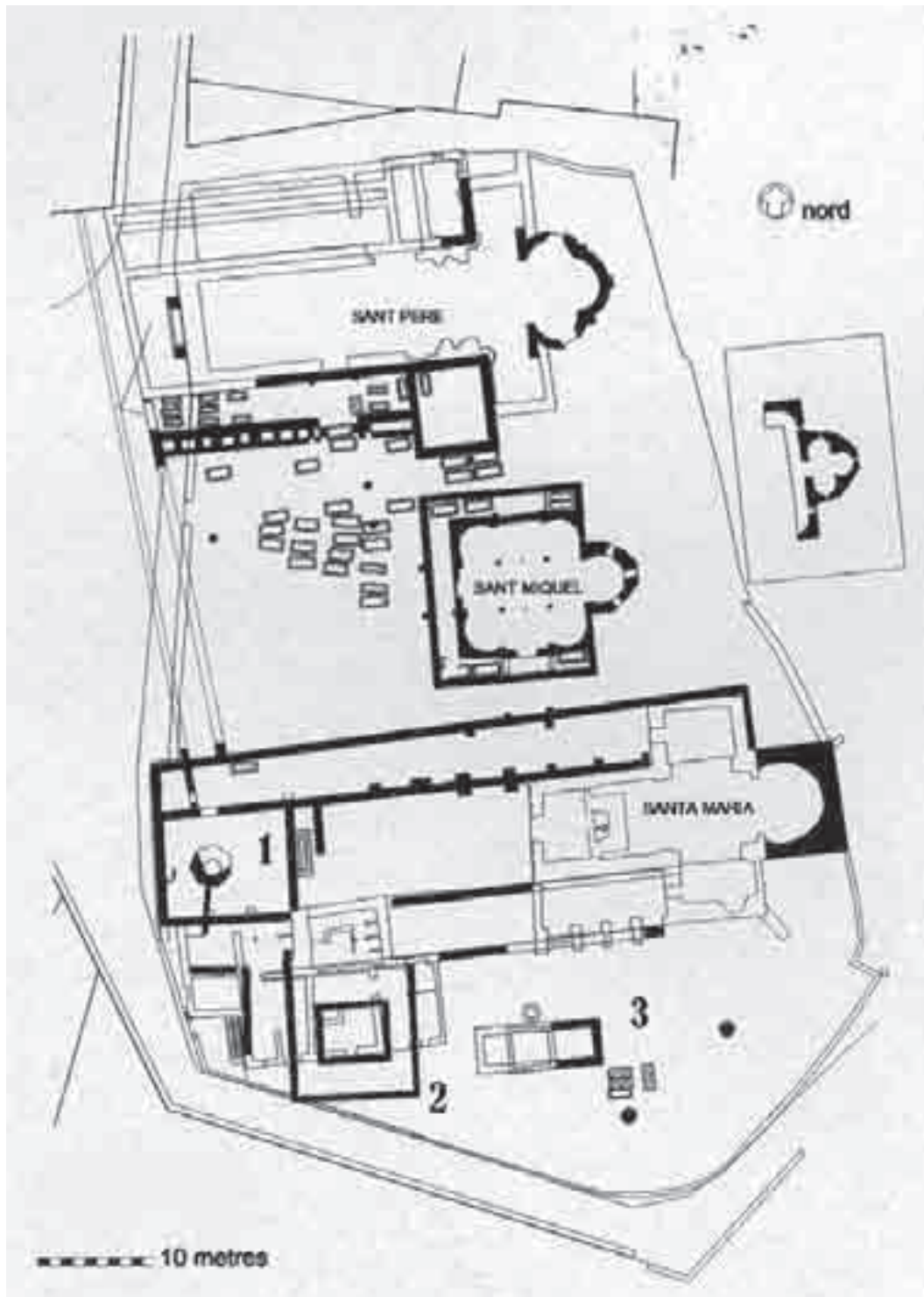

Fig. 5. Conjunto catedralicio de Terrassa, según Garcia i Llinares, Moro y Tusset. 1. Baptisterio; 2. Episcopio; 3. Santos Justo y Pastor. 
